\title{
MODERNISING THE REGULATION OF WATER POLLUTION IN NORTHERN IRELAND
}

\author{
PART TWO: RECASTING THE DISCHARGE CONSENT \\ SYSTEM AND AN AGENDA FOR FURTHER REFORM \\ Sharon Turner, Lecturer in Law, Queen's University of Belfast* \\ INTRODUCTION
}

Part Two of this extended analysis of the Water (Northern Ireland) Order $1999^{1}$ will address two issues. First, it will analyse the extensive changes made to one of the core regulatory mechanisms used to prevent and control freshwater pollution in Northern Ireland: namely, the discharge consent system. Second, it will identify an agenda for further reform of the regulatory framework governing Northern Ireland's aquatic environment.

National and European Union policy on freshwater conservation has consistently emphasised the need to maintain and improve the quality of freshwater, not only because it is a vital economic resource for industry and agriculture, but also because it is a fundamental and highly valued component of the United Kingdom's environment and ecology. ${ }^{2}$ Although the United Kingdom and the European Commission are both committed to developing economic instruments as alternative strategies for delivering environmental protection, administrative regulation will remain at the heart of national and European policy on the environment for the foreseeable future. $^{3}$ Given that the discharge consent system plays a pivotal role in the regulation of the aquatic environment, it is vital that the legal framework governing this regulatory mechanism gives expression to contemporary

\footnotetext{
* The author would like to thank Professor Colin Reid (University of Dundee), Professor Richard Macrory (University College London), Professor Brigid Hadfield (Queen's University, Belfast) and Clive Mellon (Senior Conservation Officer, RSPB(NI)) for their comments on earlier drafts of this work. Thanks are also due to my research assistant Sharon Thompson. In addition, the author would like to acknowledge the funding provided by the Law School, Queen's University Belfast, which supported the research of this paper. Part I of this article is published in (2000) 51 NILQ 65.

1 SI 1999/662 (NI 6).

2 This Common Inheritance: Britain's Environmental Strategy, (1990) Cm 1200, Chapter 12; Sustainable Development: The United Kingdom Strategy, (1994) Cm 2426, Chapter 8; Better Quality of Life: A Strategy for Sustainable Development for the United Kingdom, (1999) Cm 4345, at pp 76-78.

3 This Common Inheritance, ibid, at p 13 (paras. 1.26-32); Sustainable Development: The United Kingdom Strategy, ibid, p 34 (paras 3.20-21); A Better Quality of Life, ibid, at pp 26-27; Towards Sustainability, the EC's Fifth Action Programme on the Environment, 1993-2000, OJ C138, 17 May 1993, Chapter 7; Bell, Ball \& Bell on Environmental Law, (4 ${ }^{\text {th }}$ ed, 1997), Chapter 5 generally and particularly pp 117-124; Bowman, "Improving the Quality of Our Water: The Role of Regulation by the NRA" (1992) 70 Public Administration, pp 565-575; Weale, "Environmental Regulation and Administrative Reform in Britain", in Majone (ed) Regulating Europe, Routledge (1996) at pp 106-130.
} 
policies and principles on the prevention and control of water pollution. However, in contrast to the consent system in Great Britain, which has been the subject of far-reaching reform during the past thirty years, ${ }^{4}$ reform of the discharge consent system operating in Northern Ireland has been considerably delayed. Not before time, the Water (NI) Order 1999 fundamentally recasts the legal framework governing the consent system in Northern Ireland and in doing so, brings this vital regulatory mechanism into line with the more sophisticated and environmentally progressive systems applying in Great Britain.

Despite the far-reaching nature of the reforms introduced by the Water (NI) Order 1999, a number of fundamental weaknesses remain at the heart of the regulatory framework governing water pollution in Northern Ireland. First, the Department of the Environment (Northern Ireland) which is responsible for administering and enforcing the system of pollution control still operates as both poacher and gamekeeper in this context. Secondly, the aquatic environment in Northern Ireland will not be afforded the degree of protection extended to freshwater in England and Wales. Thirdly, the Comptroller and Auditor General for Northern Ireland has recently raised serious questions concerning the DoE(NI)'s ability to regulate water pollution in an effective manner. To compound these problems, the Government essentially missed the opportunity presented by the making of the Water Order to lay the foundations for the implementation of the tidal wave of reform posed by the forthcoming adoption of the EC's Water Framework Directive expected later in 2000. Although each of these shortcomings is significant in its own right, collectively they will significantly undermine the legal protection afforded to the aquatic environment. In order to safeguard the future wellbeing of one of Northern Ireland's most important economic and cultural assets, further modernisation of the regulatory system is essential. Failure to do so will not only neutralise, to a considerable degree, the improvements wrought by the Water (NI) Order 1999, but also continued tolerance of comparatively lax regulation will almost certainly guarantee Northern Ireland's future as a pollution haven within the United Kingdom.

\section{SECTION I}

\section{RECASTING THE DISCHARGE CONSENT SYSTEM}

Unlike the system of water quality objectives, which was reviewed and updated in 1993, ${ }^{5}$ the system of discharge consents operating in this jurisdiction has not been overhauled in the twenty-seven years since its establishment under the Water Act (NI) $1972 .{ }^{6}$ Other than the introduction of a series of regulations during the early 1990s which required the $\operatorname{DoE}(\mathrm{NI})$ to ensure that discharge consents complied with a range of specific EC Directives, ${ }^{7}$ the core legal framework governing the administration and

4 (2000) 51 at NILQ 71-72.

5 The Water and Sewerage Services (Amendment) (NI) Order 1993, SI 1993/3165 (NI 16). For a discussion of the reform of water quality control in Northern Ireland, see S. Turner and K. Morrow, Northern Ireland Environmental Law, Gill and Macmillan (1997), at pp 189-218.

6 c.5.

7 S. Turner and K. Morrow, ibid, Chapter 5 at pp 189-238. 
enforcement of consented discharges remained unchanged. Not surprisingly, the strategies and policies underpinning this important regulatory mechanism fell considerably behind its more environmentally sound counterparts applied by the Environment Agency (EA) in England and Wales and the Scottish Environment Protection Agency (SEPA). The consultation process concerning the review of the Water Act (NI) 1972 was launched in 1993; however, a further five years elapsed before the Government finally made the Water (NI) Order 1999. ${ }^{8}$ Despite its lengthy gestation, the new Order is not expected to come into force for at least another year, but when it does, it will fundamentally overhaul the entire legal framework governing discharge consents in Northern Ireland. Although the DoE(NI), like the EA and SEPA, will retain a wide discretion in the exercise of its new powers under the Order, the Department will now be responsible for administering and enforcing a consent system that almost completely approximates with the more sophisticated and environmentally sound controls imposed on consented discharges in Great Britain. ${ }^{9}$ Allied with the increased penalties for offences under the Order and DoE(NI)'s new powers to apply integrated pollution control to the most potentially polluting processes, ${ }^{10}$ Northern Ireland's new discharge consent system, if administered and enforced to its fullest extent, will afford the aquatic environment a level of protection that is compatible with the wider national and European commitment to the principle of sustainable development. ${ }^{11}$

Section I of this article will examine the four key reforms made to the consent system and to assess their likely impact on the regulator, consent holders and the aquatic environment. First, the Order opens the traditionally closed relationship between consent holders, the fisheries bodies ${ }^{12}$ and the

8 For a discussion of the reasons for this delay see, Part One of this article at (2000) 51 NILQ 65.

9 Transitional provisions have not yet been made for carrying over discharge consents granted under the Water Act (NI) 1972; however, it is anticipated that a consultation paper will be published on this issue once the Order comes into force.

10 Discharges from the most potentially polluting processes are subject to separate Integrated Pollution Control under the Industrial Pollution Control (NI) Order 1997 (SI 1997/2777 (NI 18)). Article 10(1) of the Water Order provides that a discharge or deposit made under and in accordance with a consent granted under the Order will not constitute an offence under article 23 of the 1997 Order. In addition, article 10(2) provides that a discharge or deposit made in accordance with an IPC authorisation granted under the 1997 Order will be a defence to a water pollution offence under article 9 of the 1999 Order. Similarly, article 10(2) provides that a discharge made in accordance with a waste management licence granted under the Waste and Contaminated Land (NI) Order 1997 (SI 1997/2778 (NI 19)) will not constitute an offence under article 9 of the Water Order.

11 It should also be noted that the powers conferred on the DoE(NI) under the Water Order to control and prevent water pollution will not be reallocated to other Departments as a result of the devolution arrangements contained in the Northern Ireland Act 1998, or the Belfast Agreement.

12 The Foyle Fisheries Commission and the Fisheries Conservancy Board for Northern Ireland. Both are non-departmental public bodies responsible for the application of fisheries legislation in Northern Ireland (The Fisheries Act (NI) 1966 and The Foyle Fisheries Act 1952). With the enactment of the Water Act (NI) 1972 and the establishment of the Environmental Protection Division within the $\operatorname{DoE}(\mathrm{NI})$ (the predecessor of the current Environment and Heritage Service), 
DoE(NI) to allow for a much greater degree of public participation in decision-making concerning the administration and enforcement of discharge consents. In doing so, the Order gives expression to national and EU policy on public participation in environmental decision-making. Secondly, the Order confers on the $\operatorname{DoE}(\mathrm{NI})$ statutory powers to establish a system of discharge consent fees and thereby provides the basis for implementing the EU polluter pays principle in Northern Ireland. Thirdly, the Order amends the entire framework of control governing consented discharges to reflect Government policy on 'better regulation'. Although the overall pattern is undoubtedly one of more stringent control, the Order makes certain concessions to the need for economic stability and considerably clarifies the legal position of applicants for discharge consents, consent holders and the $\operatorname{DoE}(\mathrm{NI})$. Last, but by no means least, the Water Order gives clear expression to the principle of pollution prevention. The DoE(NI)'s new powers to serve enforcement notices (discussed in Part One of this article ${ }^{13}$ ) represent the most obvious manifestation of this principle in the context of the discharge consent system. However, the principle of pollution prevention also provides the rationale for many other changes to the Department's powers to control consented discharges - all of which will be addressed in Section I of this article.

\section{Enhancing Public Participation in the Discharge Consent System}

One of the central issues raised by the Review of the Water Act (NI) 1972: A Consultation Paper ${ }^{14}$ concerned the need to ensure greater opportunities for public participation in the discharge consent system. ${ }^{15}$ In this context, public participation embraces both increased rights of access to information concerning the operation of the discharge consent system and greater public notification of, and participation in, decision-making concerning discharge

the fisheries bodies came to act as agents of the $\operatorname{DoE}(\mathrm{NI})$ in the enforcement of the 1972 Act and now carry out virtually all sampling of watercourses and effluent discharges. In addition, they may also prosecute under the fisheries legislation in the event of a fish kill.

13 (2000) 51 NILQ 65.

14 December 1993. Published jointly by the DoE(NI) and the Department of Agriculture (NI). This paper set out the DoE(NI)'s proposals for amendment of the regulatory system laid down in the Water Act (NI) 1972.

15 For a discussion of the nature and scope of the concept of public participation in contemporary environmental law, see generally: This Common Inheritance, note 2 supra, at p 10 (paras. 1.14-15, 1.20 and 1.38); Sustainable Development: The United Kingdom Strategy, note 2 supra, Chapters 31 and 32; A Better Quality of Life, note 2 supra, at p 23; Towards Sustainability, note 3 supra, Chapter 3; Royal Commission on Environmental Pollution, Setting Environmental Standards, (1998) Cm 4053, Chapters 7 and 8; Bell, Ball \& Bell on Environmental Law, note 3 supra, Chapter 7; Kramer, Focus on European Environmental Law, Sweet \& Maxwell (1992), Chapters 5 and 14; Alder \& Wilkenson, Environmental Law and Ethics, Macmillan (1999), Chapter 12; Somsen, (ed) Protecting the European Environment: Enforcing EU Environmental Law, Blackstone Press (1996); Principle 10 of The Rio Declaration on Environment and Development, adopted June 14, 1992 at Rio de Janeiro, UN Doc. A/CONF.151/5/Rev.1, (1992) 31 ILM 874. 
consents. ${ }^{16}$ Although the Water Act (NI) 1972 established a public register, the $\operatorname{DoE}(\mathrm{NI})$ was only required to record discharge consents and conditions currently in force. ${ }^{17}$ Members of the public were entitled to consult the register at all reasonable hours but they did not have a statutory right to make copies of the information contained therein. In addition, the Act was silent as to the Department's power to exclude information from the register or to levy charges for consulting the register. The Act also provided opportunities for public participation in decision-making about discharge consents; however, once again this was limited in nature and the decision to notify the public lay entirely within the discretion of the $\operatorname{DoE}(\mathrm{NI})$. In effect, the regulation of discharge consents under the Water Act (NI) 1972 was an almost exclusive relationship between applicant or consent holder and the $\mathrm{DoE}(\mathrm{NI})$ as regulator.

In contrast, the Control of Pollution Act 1974 introduced much stronger provision for public participation in the regulation of water pollution control for Great Britain. Section 41 of the Control of Pollution Act 1974 (COPA) provided that the water pollution register must include not only applications for discharge consents and consents granted, but also samples of effluent and water, the analysis of these samples and the steps taken in consequence of the information. COPA made provision for the exclusion of information from the register on specific grounds but required the Secretary of State to include certificates authorising the exclusion in the register. Water authorities were also required to record a number of other notices served under the Act. In addition, COPA required that applications for discharge consents must be notified to the public. Although public consultation could be dispensed with in certain circumstances, the Act at least sought to control the regulators' discretion in this regard. As with much of COPA, the innovative provision for public participation was not invoked until 1985 with the result that secrecy remained, until recently, as one of the hallmarks of pollution regulation in Great Britain. By the mid-1980s mounting pressure at national and European level for public participation in environmental decision-making gradually forced the Government to embrace transparency as a key element in the United Kingdom's strategy on pollution control. Building on the innovations contained in COPA, the Water Act $1989^{18}$ introduced greater rights of public access to information concerning water pollution control and further enhanced public participation in decisionmaking about the aquatic environment. Further changes in this vein were introduced by the Environment Act $1995 .{ }^{19}$ By the early 1990s, public participation in environmental decision-making was accepted at national, European and international level as a key concept underlying contemporary law and policy on the environment. ${ }^{20}$

Although EC Directive 90/313/EEC ${ }^{21}$ on freedom of access to information on the environment was implemented (late) in Northern Ireland in 1993, the

16 Ibid.

17 Section 9(9).

18 c. 15.

19 c. 25 .

20 Note 15 supra.

21 OJ L158, 23 June 1990 implemented in Northern Ireland by the Environmental Information Regulations (NI) 1993, SR 1993 No. 45. 
public participation provisions of the Water Act (NI) 1972 had remained unchanged since their enactment. Consequently, considerable legislative change was necessary to bring Northern Ireland into line with the much more generous public register provisions contained in the Water Resources Act 1991 (WRA) ${ }^{22}$ as amended. The need for far-reaching legislative reform was highlighted in the Review of the Water Act (NI) 1972: A Consultation Paper, ${ }^{23}$ which set out a series of proposals designed to bring water pollution law in Northern Ireland into line with national provisions in this regard. It is interesting to note, however, that in some instances, the Department's proposals were more progressive than those contained in the WRA 1991. Overall, the Water (NI) Order 1999 considerably increases the public's right of access to information concerning the operation of the discharge consent system and affords greater opportunities to members of the public to influence decision-making in relation to discharge consents. Regrettably, however, the Government rejected the more progressive proposals and adopted the inconsistent requirements for public consultation contained in the WRA 1991 concerning applications for discharge consent, setting and reviewing water quality objectives and consents issued without an application. The principal proposals for amendment and the Government's response will each be addressed in turn.

Proposal No.1: Applications for discharge consents should be deemed legally invalid unless they are advertised.

The Review of the Water Act (NI) 1972 pointed out that although the Water Act (NI) $1972^{24}$ empowered the $\operatorname{DoE}(\mathrm{NI})$ to require an applicant to publish notices of the application in specified newspapers, there was little public interest in water pollution control during the 1970s except amongst organisations that were directly affected like angling and rowing clubs. Environmental protection was not only a concept in its infancy in the 1970s, in Northern Ireland, this issue was also very much eclipsed by the wider security problems that engulfed the Province during that period. Consequently, it was sixteen years before the Department started to use this power. The proposal that applications for discharge consents should be deemed legally invalid unless advertised was particularly progressive and indeed exceeded the obligation imposed on the Environment Agency. Unfortunately this suggestion received only a lukewarm response. The Water Order embraces the weakest elements of the system governing applications under the WRA 1991. Schedule 1 to the 1999 Order, like Schedule $10^{25}$ to the WRA 1991, states that an application for a discharge consent must be advertised in such a manner as may be required by regulations. ${ }^{26}$ However, paragraph 1(2) goes on to provide that regulations may dispense with this requirement if the Department considers it "appropriate to do so". It is not only a matter of considerable concern that the Department retains a discretion to dispense with the obligation to advertise applications for

22 c.57.

23 Published jointly by the DoE(NI) and the Department of Agriculture (NI), December 1993.

24 Section 9(3).

25 Schedule 10 was amended by section 120, Schedule 22, para 183 to the Environment Act 1995.

26 Para 1 
discharge consents, but the Government's failure to explicitly circumscribe the Department's power in this regard is also regrettable.

In December 1996, The Control of Pollution (Applications, Appeals and Registers) Regulations 1996 came into force in England and Wales. ${ }^{27}$ These Regulations set out, inter alia, the conditions governing the advertising of applications for discharge consents under the WRA 1991. Regulation 4 provides that the Environment Agency can dispense with the obligation to advertise an application for a consent if the application is either exempt from inclusion in the public register on the grounds of national security (discussed below), or the Agency considers that the proposed discharge is unlikely to have "an appreciable effect" on the receiving waters. Before being amended by the Environment Act 1995, Schedule 10 to the WRA 1991 had conferred power on the National Rivers Authority to dispense with the requirement to advertise applications where it considered that the discharge would have "no appreciable effect" on the receiving waters. This was simply a re-enactment of the equivalent provision contained in Schedule 12 to the Water Act 1989, which in turn had retained the provision from section 36(1) of COPA 1974. Guidance on the exercise of this discretion was laid down in DoE Circular 17/84: the main test being that a change is not to be considered appreciable if there is less than a $10 \%$ increase on all relevant parameters, unless some significant environmental amenity is affected. These guidelines provoked considerable controversy. ${ }^{28}$ In particular, it was argued that a $10 \%$ decline in water quality could in some cases constitute a "minor environmental disaster, whereas in other situations, where the quality of the receiving water is especially high, it will constitute an insignificant difference to the overall water quality." ${ }^{29}$ Although the Environment Act 1995 removed the reference to the concept of an appreciable effect, its use in the 1996 Regulations makes clear that this concept still remains at the heart of the Environment Agency's discretion to dispense with the obligation to notify the public concerning an application for a discharge consent. In addition, the Regulations do not provide a statutory definition of the term, hence, as Howarth pointed out, an important publicity procedure is still left to hinge on "an avoidable degree of uncertainty". ${ }^{30}$ Draft Regulations have not yet been prepared in this context for Northern Ireland; however it is likely that the $\operatorname{DoE}(\mathrm{NI})$ will follow the approach adopted by the Environment Agency in England and Wales.

A number of further points should be noted concerning the public notification requirements for applications for discharge consents. First, it is disappointing that Schedule 1 to the Water Order does not bring Northern Ireland into line with the requirements imposed on the Environment Agency to consult with relevant bodies outside the Agency concerning applications

27 SI 1996/2971.

28 Howarth, "Water Pollution: Improving the Legal Controls" (1989) 1 Journal of Environmental Law 25, at p 34.

29 Ibid, at p 35. See also: Eastwood \& Ord, "Implementing Part II of the Control of Pollution 1974" (1986) Water Pollution Control 241; Mattews, "Part II of the Control of Pollution Act 1974: What it Means" (1987) Water Pollution Control 140.

30 Note 28 supra. 
for discharge consents. ${ }^{31}$ In the Northern Ireland context, the DoE(NI) should at least have been obliged to consult with the Northern Ireland Water Council, the Water Appeals Commission, the Council for Nature Conservation and the Countryside, the relevant fisheries board, ${ }^{32}$ the relevant district council(s) and specialist non-statutory interests. ${ }^{33}$ Under the Water Resources Act 1991,34 (WRA), the Agency's statutory consultees have six weeks within which to make representations concerning the application, and the Agency is required to consider any representations submitted within this period. Secondly, even where the $\operatorname{DoE}(\mathrm{NI})$ does require an applicant to advertise their application under Schedule 1, the Department, unlike the Environment Agency, is not placed under a statutory obligation to consider any representations made by members of the public in response to the notification. Not only is the Environment Agency under an obligation to consider public representations, ${ }^{35}$ a statutory period of six weeks is laid down for public consultation. While the Secretary of State (in England and Wales) retains the power to change this period by regulation, the Water (NI) Order 1999 does not require the $\operatorname{DoE}(\mathrm{NI})$ to allow a specific period for public consultation. Finally, it should be noted that the public notification requirements concerning discharge consents issued without an application (under paragraph 4 , Schedule 1 - discussed below) are more stringent than those applying in relation to consents issued on foot of an application. As is the case under Schedule 10 to the WRA 1991, the Department is obliged to publish notice of such a consent "in such a manner as may be prescribed". Under the Control of Pollution (Applications, Appeals and Registers) Regulations 1996 (which govern the notification of such consents in England and Wales), the Environment Agency may only dispense with the requirement to advertise if the application is exempted from inclusion in the public register on the grounds of national security or commercial confidentiality. ${ }^{36}$ The Environment Agency does not retain a discretion to dispense with the obligation to advertise in this context using the "appreciable effect" test.

Proposal No.2: The DoE(NI) should be empowered to require the Water Appeals Commission to hold a public inquiry, either alone or jointly with the Planning Appeals Commission, to consider objections to applications for discharge consents or where the proposed discharge is environmentally critical. The Department should be required to advertise its decision to hold a public inquiry.

31 Schedule 10, para 2. This requirement was introduced into the WRA 1991 by the Environment Act 1995. Regulation 5 of the Control of Pollution (Applications, Appeals and Registers) Regulations 1996 (SI 1996/2971) lists local authorities, other Ministers, local fisheries committees and the harbour authority.

32 The Foyle Fisheries Commission or the Fisheries Conservancy Board for Northern Ireland. See also note 12 supra.

33 For example: the RSPB(NI), the Ulster Wildlife Trust, the National Trust, World Wide Fund for Nature (NI), Friends of the Earth (NI), the Northern Ireland Environmental Link, the Conservation Volunteers (NI).

34 Schedule 10.

35 Schedule 10, para.2(3).

36 Schedule 1, para 1. 
These proposals were only partially adopted by the new Water Order. Schedule 1 confers a new power on the Department to direct the Water Appeals Commission (WAC) ${ }^{37}$ to conduct a public inquiry into applications for discharge consents. ${ }^{38}$ Surprisingly, the Order does not confer a power to direct that the Planning Appeals Commission (PAC) ${ }^{39}$ and the WAC conduct joint inquiries where a proposed development raises both pollution control and planning issues. Instead, paragraph 3(4) provides that where the DoE(NI) receives public representations in response to an advertised consent application which are relevant to a public inquiry to be held by the PAC, the Department may direct the PAC to consider those representations. However, in both instances, the $\operatorname{DoE}(\mathrm{NI})$ is obliged to consider the report on the public inquiry in making its decision whether to grant the discharge consent.

While the Department's power to direct that a public inquiry be held is undoubtedly welcome, public participation in the inquiry process is kept somewhat at arm's length despite the ethic underlying the concept of a public inquiry. To begin with, the Department is only obliged to notify the applicant for the consent and the relevant fisheries body ${ }^{40}$ of a decision to direct the WAC to hold an inquiry or a direction to the PAC to consider representations made in response to the application. ${ }^{41}$ Even members of the public or environmental non-governmental organisations (NGOs) who have submitted representations to the Department concerning an advertised application for a discharge consent are not entitled to such notification. A further inconsistency with the concept of public participation lies in the fact that only the applicant and the relevant fisheries bodies are given a statutory right to appear and be heard at the inquiry. The Consultation Paper recommended that the right of appeal normally granted to an applicant and the fisheries bodies should be extinguished when a public inquiry is held as a second hearing of the issues would be inappropriate in such circumstances. ${ }^{42}$ To compensate for this loss, it was recommended that the fisheries bodies (but not the applicant) should be given a statutory right to appear and be heard at the inquiry. Article 13(4) does extinguish the right of appeal as suggested, but Schedule 1 paragraph 3(5) affords only the applicant and the fisheries bodies statutory rights to appear and be heard. Third parties are neither afforded a right to appeal a decision to grant a discharge consent nor a right to appear and be heard at a public inquiry conducted under the Water

37 The Water Appeals Commission is an independent non-departmental body established under article 7 of the Water and Sewerage Services (NI) Order 1973 (SI 1973/70 (NI 2)).

38 Para 3

39 The Planning Appeals Commission is an independent non-departmental body established under the Planning (NI) Order 1972. The PAC now exists by virtue of article 110(1) of the Planning (NI) Order 1991. For further discussion of the powers and status of the PAC, see: Dowling, Northern Ireland Planning Law, Gill and Macmillan (1995), at pp 16-20.

40 Either the Fisheries Conservancy Board for Northern Ireland or, if the discharge is to be made in the Derry area, the Foyle Fisheries Commission.

41 This is also the case under the Water Resources Act 1991. In this context the applicant may include the applicant for the discharge consent, and the applicant for planning permission, para 3(6).

42 Para 5.2.7. 
(NI) Order 1999 - not even directly interested parties such as local residents or NGOs. Objectors in Great Britain are in a similarly weak position.

In this context it is also interesting to note that the Consultation Paper proposed that public inquiries should be held either to consider objections received in response to an advertised application or where the proposed discharge was considered to be "environmentally critical". During their response to the Consultation Paper the Royal Society for the Protection of Birds (NI) (RSPB (NI)) described the phrase 'environmentally critical' as being fraught with potential inconsistencies and subjectivity. To ensure that such discharges were correctly and consistently identified, the RSPB(NI) urged the Department to implement integrated management plans for all major catchments in Northern Ireland. In addition, the RSPB(NI) recommended that there should be stronger representation of conservation NGOs in the composition of the Northern Ireland Water Council ${ }^{43}$ to assist in the identification of such discharges and to facilitate further consideration of the conservation issues raised by each application. The Government's response was to omit reference to this difficult phrase. Indeed, as is the case under the WRA 1991, no statutory pre-conditions are imposed on the Department's power to call a public inquiry. More importantly, however, in the context of public participation is the Government's refusal to include a representative from any of Northern Ireland's environmental NGOs in the composition of the Water Council. Despite being a potent means of enhancing the quality of public debate on the environment and ultimately the quality of decision-making in this regard, no provision is made for representation of even the principal environmental interest groups operating within the Province.

\section{Proposal No. 3: The DoE(NI) should be required to advertise appeals in relation to discharge consents and decisions to review discharge consents.}

Both proposals were rejected. Neither the DoE(NI) nor the Environment Agency is required to advertise their intention to review a discharge consent, despite the fact that a review may lead to a significant change in the consented discharge. Although it is disappointing that the Government did not take the opportunity posed by the making of the Water Order to depart from this dubious position, what is more remarkable is that the Order does not bring the $\operatorname{DoE}(\mathrm{NI})$ into line with the position in England and Wales concerning public notification of appeals. Section 91(2B) of the Water Resources Act 1991 (WRA) provides that appeals against decisions concerning discharge consents shall be advertised if this is required by regulations adopted under the Act. In 1996 the Control of Pollution (Applications, Appeals and Registers) Regulations $1996^{44}$ were adopted under these powers. Regulation 12(2) imposes an absolute obligation on the Secretary of State to publish notices of appeals within 21 days of the hearing.

43 The Northern Ireland Water Council is now governed under article 58 of the 1999 Order. Its function is to advise the $\operatorname{DoE}(\mathrm{NI})$ and the DANI in relation to their functions under the 1999 Order and the DoE(NI) in relation to its functions under the Water and Sewerage Services (NI) Order 1973.

44 SI 1996/ 2971 
The new Water Order does not impose an equivalent obligation on the $\mathrm{DoE}(\mathrm{NI})$, nor does it confer power on the Department to adopt regulations that might require public notification of appeals against decisions concerning discharge consents. This anomaly is further compounded by the fact that third parties are completely excluded from participating in the appeals process. Under article 13 of the 1999 Order only the applicant or holder of the consent and the two fisheries bodies are conferred with rights to appeal the Department's decisions in relation to discharge consents. The Consultation Paper did not make any proposal to depart from this position. The lack of an obligation to provide public notification or powers to make such provision is also anomalous given that article 30 requires that all appeals in relation to discharge consents under article 13 must be recorded in the register established under the Order.

\section{Proposal No. 4: The categories of information contained on public registers concerning the operation of the discharge consent should be expanded.}

Consistent with Government and EU policy on public participation, ${ }^{45}$ the Water (NI) Order 1999 considerably expands the range of information that must be recorded on the public register maintained by the $\operatorname{DoE}(\mathrm{NI})$ concerning the administration and enforcement of the Order. Indeed, it should be noted that, with the exception of one significant omission, the Order brings the Northern Ireland water pollution register fully into line with the equivalent requirements laid down in the Water Resources Act $1991^{46}$ as amended by the Environment Act 1995. ${ }^{47}$ The Order also brings the provisions governing access to the register into line with the Environmental Information Regulations (NI) $1993^{48}$ which implement Directive 90/313/EEC ${ }^{49}$ on freedom of access to environmental information. As currently drafted, the terms of the Freedom of Information Bill, which is discussed further below, will not directly affect the public's right to information held on statutory pollution registers such as that established under the Water Order. However, when it is enacted, Regulations will be adopted pursuant to the Freedom of Information Act for the purposes of implementing the requirements of the 1998 Århus Convention ${ }^{50}$ in the United Kingdom. These Regulations will relate to the operation of pollution registers and will undoubtedly necessitate the amendment of the terms of the Water Order governing the pollution register. Finally, it should be noted

45 Note 15 supra.

46 Sections 190, 191A and 191B.

47 Section 120, Schedule 22, para 170.

48 SR 1993 No. 45.

49 OJ L 158, 23 June 1990.

50 UN Economic Commission for Europe Convention on Access to Information, Public Participation in Decision-Making and Access to Justice in Environmental Matters, signed at Århus, Denmark in June 1998; ECE/CEP/43. The full text of the Convention is available at www.eel.nl/treaties/CEP43E.htm. The "Århus Convention" (as it has become known) was signed by 39 European Governments (including the United Kingdom) and the EU itself. For general discussion of the key terms of the Århus Convention see ENDS Report 279, pp 43-44 and 292, pp 43-44. It should be noted that the adoption of the Århus Convention will lead to the adoption of an improved EC Directive on access to environmental information. 
that given the confines of space and the fact that these provisions are not unique to water law, the new provisions governing Northern Ireland's water pollution register will not be the subject of detailed analysis in the present context. ${ }^{51}$

Article 30 of the Water Order requires the Department to maintain a public register that records virtually every aspect of the administration and enforcement of the Order. The modernised register will effectively enable environmental interest groups and individuals to obtain a three dimensional picture of how the core elements of the regulatory system are administered and enforced: namely, the discharge consent system, the system of water quality objectives and Integrated Pollution Control for prescribed processes. Not only will the public be able to identify the location and nature of consented discharges, but also the extent to which the Department is prepared to refuse its consent. In addition, the register will enable members of the public to monitor the Department's exercise of its enforcement and administrative powers under the Order - particularly the extent to which the $\operatorname{DoE}(\mathrm{NI})$ takes action to prevent pollution incidents and prosecutes offences under the Order. One notable omission are the discharge standards set for the DoE(NI)'s sewage and water treatment works. Despite the recommendation made by the Review of the Water Act (NI) 1972: A Consultation Paper that such information be included in the register, this proposal was not adopted by the Government. Consequently, this information remains available to the public only under the discretionary register $^{52}$ established by the Department in 1996 and the general right to environmental information laid down in the Environmental Information Regulations (NI) 1993. It is also hoped that the $\operatorname{DoE}(\mathrm{NI})$ will exercise its powers under article 30 to adopt Regulations equivalent to those adopted by the Environment Agency ${ }^{53}$ which prescribe when entries must be made and when information may be removed. The provisions governing the practical arrangements concerning access are also brought into line with the terms of the WRA 1991 and the requirement of the Environmental Information Regulations (Northern Ireland) 1993. Whereas the Water Act (NI) 1972 simply entitled the public to consult the register at all reasonable hours, article 30(3) of the Order introduces the additional requirements that consultation must be free of charge and reasonable facilities must be provided for obtaining copies of entries in the register - although a reasonable charge can be levied for copies made.

There are, however, a number of weaknesses in the water pollution register all of which are shared with the equivalent register maintained under the Water Resources Act 1991. Neither the Environment Agency nor the $\operatorname{DoE}(\mathrm{NI})$ is required to record the fact that they have initiated a review of a

51 Bell, note 3 supra, pp 162-164.

52 The informal register was established as a result of commitments made to the House of Commons Environment Committee and targets set down in the Environment Service Corporate Plan 1994-97, at p 32 . In relation to the commitments made to the House of Commons Committee, see the Minutes of Evidence submitted to the Committee by the Northern Ireland Office on July 19, 1993; HC 861-I, Session 1992-93, para 24.2.

53 The Control of Pollution (Applications, Appeals and Registers) Regulations 1996, SI 1996/2971. 
discharge consent. In light of the fact that public notification of reviews is not mandatory (as opposed to an application for a variation), this aspect of the regulatory function is essentially conducted in complete secrecy. In addition, neither the Water Order nor the WRA 1991 places the regulator under an obligation to record the fact that a public inquiry was conducted. Once again, given that public notification of an impending inquiry is not mandatory, this omission represents another important gap in the range of information provided to the public in this context. Neither the DoE(NI) nor the Environment Agency is required to record convictions for giving false information, or refusals to comply with directions requesting information concerning discharges to water. Another significant omission from both the Water Order and the WRA 1991 is that neither register must record the payment of compensation. Provision is made in several contexts for payment of compensation to potential or actual dischargers. It is submitted that information relating to the frequency and amounts of compensation paid would provide valuable information concerning the extent to which the taxpayer in the United Kingdom absorbs the costs of pollution control.

Important new controls have also been imposed on the exclusion of information from the water pollution register. Where previously the Water Act (NI) 1972 was silent as to the exclusion of information from the register, the Water Order explicitly addresses this important issue. As is the case under the WRA 1991, ${ }^{54}$ information can be excluded from the register if it is necessary in the interests of national security or commercial confidentiality. However, where information is excluded, the DoE(NI), like the Environment Agency, must insert a statement into the register indicating the existence of the excluded information..$^{55}$ The strength of this requirement is unfortunately blunted by the fact that neither regulator is required to specify the grounds on which information is excluded. This weakness is however somewhat ameliorated by the wider rights and duties concerning public access to environmental information laid down in the Environmental Information Regulations (NI) 1993. Although the Regulations do not apply to environmental information that must be contained in public registers, ${ }^{56}$ such information does not entirely escape their control. Regulation 6 provides that the practical arrangements made for the provision of environmental information, which must be released to the public under the terms of other statutory provisions, must be such as to secure conditions identical to those required under the Regulations. Regulation 4(2) provides that where a public body decides to refuse access to requested information, the reasons for the refusal must be provided. It is therefore arguable that a statement indicating the exclusion of information from the register maintained under the Water Order should always specify the reason on which the exclusion is based. Certainly, if the DoE(NI) were requested to provide an explanation for the exclusion and refused to do so, it would be acting in breach of regulation 6 . Regrettably, members of the public are not granted a right of appeal against a decision of the $\operatorname{DoE}(\mathrm{NI})$ or the Secretary of State for Northern Ireland to

54 Sections 191A and 191B inserted into the WRA 1991 by the Environment Act 1995.

55 Article 30(2).

56 Regulation 3(c). 
exclude information from the water pollution register, nor is there an equivalent right of appeal against a refusal under the 1993 Regulations.

As already stated, the Freedom of Information Bill does not relate directly to pollution registers. Indeed, due to the considerably more generous provision for public access to environmental information under EC Directive 90/313/EEC on freedom of access to environmental information, the Government will have to disapply important sections of the Bill to ensure compliance with the Directive. However, Regulations will be adopted pursuant to the Act (when it is finally enacted) for the purposes of implementing the terms of the 1998 Århus Convention, ${ }^{57}$ which will relate to the operation of pollution registers. ${ }^{58}$ Article 5.2 of the Convention requires Governments to ensure that practical arrangements are made by public authorities to ensure that environmental information is made available to the public in a "transparent" and "effectively accessible" manner. Article 5 goes on to identify a number of specific means by which this objective may be achieved, in particular, by providing information contained in registers free of charge and ensuring that such information becomes progressively available through electronic databases which are easily accessible to the public through the Internet. Article 4 of the Convention governs the grounds for refusing access to environmental information. While Article 4 does not change the traditional grounds for exempting information from disclosure, it requires the balance of advantage to be shifted in favour of releasing information that would normally be exempted. Whereas Article 32 of the Water Order empowers the $\mathrm{DoE}(\mathrm{NI})$ to exempt information from disclosure on the grounds that it is commercially confidential if its release "would prejudice to an unreasonable degree the commercial interests of any individual or person", Article 4.4(d) of the Convention considerably limits the type of information that could be exempted on these grounds. It provides that the safeguard for commercial confidentiality may only be used "where confidentiality is protected by law in order to protect a legitimate economic interest" but in any event, "information on emissions which is relevant for the protection of the environment shall be disclosed". Volunteered information is only protected from disclosure under the Convention where it has been requested "without that party being under or capable of being put under a legal obligation" to pass it on to an authority. ${ }^{59}$ In contrast, Article 32(4) of the Water Order currently enables the $\operatorname{DoE}(\mathrm{NI})$ to exempt information on the grounds that it is commercially confidential even where it has been furnished to the Department under a statutory duty. Finally, Article 4.4 imposes an overarching obligation which further shifts the balance of advantage in favour of disclosure. Article 4.4 concludes by providing that all grounds for refusing disclosure "shall be interpreted in a restrictive manner, taking into account the public interest served by disclosure and taking into account whether the information requested relates to emissions to the environment". Although the Water Order empowers the DoE(NI) to disclose information notwithstanding that it is deemed to be commercially confidential where there is a public interest in doing so, there is no equivalent power to disclose information that would normally be exempted

57 Note 50 supra.

58 Draft Regulations will be published at the end of the year 2000.

59 Article 4.4(g). 
on the grounds of national security. Furthermore, the Order is silent as to the exemption of information concerning emissions to the environment. It is clear therefore that Article 32 of the Water Order will need to be amended to take account of the requirements of the Arrhus Convention.

\section{Implementing the 'Polluter Pays' Principle}

The 'polluter pays' principle encapsulates one of the most important shifts in contemporary environmental policy during the past decade. ${ }^{60}$ Although originally popularised by the Organisation for Economic Co-Operation and Development in the early 1970s, the European Union is largely responsible for its integration into mainstream environmental policy in the United Kingdom. Because the environment was traditionally regarded as a 'free' economic resource, pollution has generally been perceived as having no economic cost. Consequently, although polluting emissions and discharges to the environment have been subject to regulation since the early nineteenth century, the taxpayer has absorbed the cost of administering the system of control. By the same token, penalties for pollution offences were low and the principal responsibility for clean-up lay with the regulator - and therefore the taxpayer. As consciousness of the true impact of pollution came to the political fore, this perception began to change. By the mid-1980s the European Commission had adopted the polluter pays principle as one of the key concepts underlying EC policy on the environment. ${ }^{61}$ In essence, the Community adopted the view that those persons whose activities give rise to actual or potential pollution should pay the costs of policing and remedial measures. $^{62}$ During the same period, the Government under Mrs Thatcher expressed its wider political commitment to the ideology of privatisation and the development of market-based regulatory strategies. Although it was legally obliged to do so as a Member State of the EU, the Government, not surprisingly, readily embraced the polluter pays principle as part of the United Kingdom's environmental law and policy. In 1990, This Common Inheritance $^{63}$ stated that administrative regulation, working alone, was an

60 For a discussion of the nature and role of this principle in contemporary environmental law and policy see generally: This Common Inheritance, note 2 supra at p 13 (para 1.28), p 136 (para 10.3) and p 168 (paras. 12.23-25); Sustainable Development: The United Kingdom Strategy, note 2 supra, Chapter 3, para 3.16; A Better Quality of Life, note 2 supra, at p 23; Towards Sustainability, note 3 supra, Chapter 7, section 7.4; Hughes, Environmental Law, (3 ${ }^{\text {rd }}$ ed 1996), at pp 21-23; Kramer, E.C. Treaty and Environmental Law, (2 $2^{\text {nd }}$ ed, 1995), at pp 5657; Kramer, (1992) note 15 supra, Chapter 11; Jans, "Objectives and Principles of EC Environmental Law", in Winter, (ed.), European Environmental Law: A Comparative Perspective, Darthmouth (1996), at pp 285-287; Kiss \& Shelton, Manual of European Environmental Law, (2 ${ }^{\text {nd }}$ ed, 1997), at p 43; Alder \& Wilkenson, note 15 supra, at pp 171-184; Sands, Principles of International Environmental Law: Volume 1, Manchester University Press (1995), at pp 213 217; O’Riordan, Ecotaxation, Earthscan (1997).

61 See: Kramer, (1992) note 15 supra, Kramer, (1995) note 60 supra, and Towards Sustainability, note 3 supra. It should also be noted that the 'polluter pays principle' was enshrined in article 130R of the EC Treaty in 1992 as a result of amendments made by the Treaty on European Union. Article 130R has recently been renumbered as article $174 \mathrm{EC}$ under the Treaty of Amsterdam.

62 Kramer, ibid.

63 Note 2 supra, and at p 13, para 1.26. 
expensive and ineffective means of controlling environmental pollution. Although the Government maintained that regulation would remain at the heart of Britain's system of environmental control for the foreseeable future, ${ }^{64}$ This Common Inheritance emphasised the Government's commitment to developing new market-based instruments for environmental protection. In particular, This Common Inheritance made it clear that the polluter pays principle would underlie all forms of environmental controls in the United Kingdom, including the system of administrative regulation. ${ }^{65}$

The polluter pays principle was integrated into the system of regulation governing water pollution in England and Wales in three principal ways: namely through increasing the maximum penalties for water pollution, strengthening polluters' liabilities for pollution prevention and clean-up costs and introducing a system of discharge consent fees. The Water Act 1989 introduced powers for the establishment of a system of discharge consent fees; these powers were exercised almost immediately and a system came into force in July $1991 .{ }^{66}$ Penalties for water pollution offences were increased significantly by the Environmental Protection Act 1990.67 Prospective polluter's liabilities for pollution prevention and polluter's liabilities for clean-up costs have been gradually increased in England and Wales through successive reforms, particularly under the Water Act 1989 and the Environment Act 1995. ${ }^{68}$ As usual, several years elapsed before equivalent measures were introduced in Northern Ireland. The first steps to implement the polluter pays principle in Northern Ireland were taken relatively quickly; however, this momentum evaporated as the programme of reform turned to focus almost exclusively on the implementation of EC Directives on the environment. Three years passed before equivalent penalties for water pollution offences were introduced into Northern Ireland in 1993. ${ }^{69}$ A decade passed before the introduction of equivalent powers to introduce discharge consent fees - now contained in article 11 of the Water (NI) Order 1999. The Water Order also finally introduces the enhanced liabilities for pollution prevention and remediation introduced in England and Wales in 1989 and the subsequent amendments to the Water Resources

64 Ibid.

65 Ibid, and at Annex A.

66 These powers were originally introduced under Schedule 12, para 9 of the 1989 Act. They were subsequently consolidated in section 131 of the Water Resources Act 1991 and are now contained in the general charging provisions of sections 41 42 of the Environment Act 1995. Equivalent charges are being introduced in Northern Ireland in respect of licences granted under the Waste and Contaminated Land (NI) Order 1997 (SI 1997/2778 (NI 19)) and the Industrial Pollution Control (NI) Order 1997 (SI 1997/2777 (NI 18)).

67 c. 43 .

68 In this regard, see the discussion of anti-pollution works notices in Part One of this article, (2000) 51 NILQ 65 et seq.

69 Introduced under article 17 of the Water and Sewerage Services (Amendment) (NI) Order 1993 (SI 1993/3165 (NI 16)). These penalty provisions have now been consolidated in the Water (NI) Order 1999. However, in Control of River Pollution in Northern Ireland; HC 693, Session 1997-98, at p 81, the Comptroller and Auditor General for Northern Ireland expressed his concern that courts in Northern Ireland were not making use of the increase in the penalty ceiling for water pollution offences. See also Part One of this analysis, (2000) 51 NILQ 65 et seq. 
Act 1991 made by the Environment Act 1995. The Department's new powers to impose prevention and clean-up obligations were addressed in Part One of this article $;^{70}$ however, the present section will focus on the nature and scope of its powers to establish a system of charges for discharge consent fees.

Article 11 of the 1999 Order provides that the DoE(NI) may introduce a scheme of charges for discharge consents in Northern Ireland. ${ }^{71}$ Charges may be imposed on applications for new consents, applications for variations of existing consents, retrospective consents granted without an application and consents granted under the Water Act (NI) 1972. ${ }^{72}$ Either the applicant or consent holder will be liable for payment of the fee. Failure to do so will entitle, but not oblige the Department to revoke the consent. As is the case in England and Wales, cost recovery is the essential philosophy underlying the charging scheme. Article 11(5) provides that the charging scheme must be sufficient to ensure, in so far as it is reasonably practicable, that the costs incurred by the Department in exercising its powers under the Order in relation to discharge consents are covered. Consequently consent fees will cover not only the costs incurred in making the initial decision to grant a consent, but also the Department's expenditure in monitoring the discharge during the life of the consent. ${ }^{73}$ Although environmental interest groups broadly welcomed the introduction of discharge consent fees in Northern Ireland, the Royal Society for the Protection of Birds (NI) expressed their concern during the consultation process that the Department's charging powers were constrained by cost recovery. The RSPB(NI) voiced its support for the wider use of economic instruments in environmental policy and in particular called for the amendment of the proposed draft Order to allow for the introduction of incentive charging for water pollution. In this regard the Society pointed to the Government's Statement of Intent on Environmental Taxation $^{74}$ and to the proposals for incentive charging set out by the Department of the Environment, Transport and the Regions' 1998 consultation on Economic Instruments for Water Pollution. ${ }^{75}$ Regrettably, this proposal was not adopted.

70 Ibid, at pp.20-31.

71 This system will not apply to effluent from domestic septic tanks serving single dwellings.

72 Article 11(1). Article 11(6)-(8) imposes strict public notification requirements in relation to proposals to introduce discharge consent fees. The DoE(NI) must publish notices of a proposal to introduce a scheme of charges which specify the period within which representations may be made and must consider any representations duly made. Unlike the public consultation requirements relating to applications for discharge consents or variations thereof, the Department must bring the provisions of any charging scheme to the attention of persons likely to be affected by it. The Department does not have a residual power to dispense with this requirement.

73 In this regard, the fee will cover the costs incurred in sampling discharges, inspecting discharges, discharge related impact monitoring, work on the review of consents, laboratory services and direct administration connected to these matters.

74 HM Treasury (1997), Environmental Taxation: Statement of Intent; HM Treasury Press Office, 2 July, 1997.

75 Consultation Paper, DETR (1997). 
Although the $\operatorname{DoE}(\mathrm{NI})$ is not obliged to establish a scheme of charges, the Government's commitment to the polluter pays principle is such that the introduction of discharge consent fees in Northern Ireland is inevitable. The $\operatorname{DoE}(\mathrm{NI})$ has not yet published detailed proposals for a charging scheme; however, the Compliance Cost Assessment accompanying the proposal for a draft Water (NI) Order noted the Department's intention to adopt the approach used by the Environment Agency in calculating charges in England and Wales. Consent charges in England and Wales are set according to a formula comprised of three separate elements, namely the volume of effluent produced, its content and the characteristics of the receiving water. Weighted bands have been established for each of these three elements; for example, in relation to volume, the greater the volume of effluent being discharged, the greater the weighting accorded to that element. The weightings accorded to each element of the discharge are multiplied together to give a final figure which in turn is multiplied by a national financial factor. By this means, the consent fee not only shifts the cost of regulation from the taxpayer to the polluter, but also provides the polluter with an incentive to reduce the volume or improve the quality of effluent being discharged as this would reduce the annual monitoring charge. Uniformity of charging is one of key principles underlying the charging system operating in England and Wales. The continuation of this pattern of charging consistency is likely to be fundamental to the debate surrounding the introduction of consent fees in Northern Ireland. However, in light of the fact that fees for Integrated Pollution Control authorisations ${ }^{76}$ in Northern Ireland are already less expensive than the equivalent fees imposed in England and Wales, it is certainly possible that fees charged for consents granted under the Water Order will also be less expensive than the fees imposed for consents granted under the WRA 1991. However, cheaper consent fees will also raise the spectre of Northern Ireland becoming a more attractive location for polluting industries than elsewhere in the United Kingdom.

One final, but significant, problem surrounding the implementation of discharge consent fees in Northern Ireland concerns the practical problems faced by the DoE(NI)'s Environment and Heritage Service (EHS) in making the necessary arrangements to introduce the charging system. Although work began on the development of a cost recovery system in 1996, the Comptroller and Auditor General's 1998 report concerning the operation of the EHS made it clear that much work remained to be done before a system of discharge consent fees could be introduced in Northern Ireland. ${ }^{77}$ The Auditor General report revealed that the EHS has no written policies or procedures or guidance either for its own staff or for its agents on the recovery of costs arising from pollution incidents. ${ }^{78}$ The EHS told the

76 Integrated Pollution Control authorisations are granted under the Industrial Pollution Control (NI) Order 1997.

77 Control of River Pollution in Northern Ireland; HC 693, Session 1997-98, Part 8, pp 77-81.

78 Ibid, p 79, para 8.8. In the absence of guidance on costs, the Auditor General examined what occurred in practice and reported the following (pp 79-80, para 8.10)): The costs incurred by the EHS or its agents in investigating the sources of pollution and taking samples are neither recorded nor recovered. Where a successful prosecution is taken, the costs of analysis are recovered through the courts, but only that proportion of such costs as are necessary to establish the case 
Auditor General that it was planning to draw up operational guidelines for dealing with incident costs when the new Water Order became law. ${ }^{79}$ While the Auditor General recommended that work should progress on the preparation of an accurate assessment of the full costs of all consent work, the development of a charging strategy consistent with the policy objective of full cost recovery, and the development of a system to enable management to monitor the extent to which costs are being recovered, ${ }^{80}$ the Auditor General's Report regrettably gave no indication as to how far work in this regard had progressed. Taking 1992 as the original target date for the enactment of the Water Order, the Auditor General estimated that by April 1998 , the delays in conferring on the $\operatorname{DoE}(\mathrm{NI})$ the powers necessary to introduce a charging system had already cost the taxpayer up to $£ 5$ million. ${ }^{81}$ In light of the under-developed nature of the EHS' cost recovery system, it is unlikely that this central aspect of the polluter pays principle will be implemented in Northern Ireland in the short to medium term.

\section{'Better Regulation' of the Discharge Consent System}

One of the major policies underlying the reform of the discharge consent system is the Labour Government's policy of "better regulation". ${ }^{22}$ Like the Conservative Government's policy of deregulation, ${ }^{83}$ better regulation is aimed at streamlining and simplifying regulatory controls; however, it also seeks to refine the system of environmental regulation to better reflect sustainable development objectives. In February 1998 the Government published Opportunities for Change ${ }^{84}$ - a consultation paper setting out its vision of sustainable development and proposals for revising the United Kingdom's strategy for achieving sustainability in this country. Opportunities for Change reiterated previous national policy on sustainable

for prosecution. In relation to clean-up costs, only the cost of materials and hire of equipment used and the staff costs of certain agents employed by the EHS are recovered from polluters. However, EHS staff time is neither recorded nor recovered. In relation to enforcement action, legal costs are recovered if the prosecution is taken by one of the fisheries bodies - private sector legal services are used and their costs are recovered through the courts. However, if the EHS prosecutes through the Water Act (NI) 1972, legal services are arranged via the DPP and no costs are recovered. In the event of a successful prosecution, only those costs (except clean-up costs) which can be recovered direct from the polluter are recoverable through the courts.

79 Ibid, p 79, para 8.9.

80 Ibid, p 78, para 8.6.

81 Ibid, p 78 at para 8.6. The Auditor General did, however, note that the figure may be less if the EHS had phased consent fees in gradually as occurred in England and Wales.

82 Explanatory Document for a Proposal for a Draft Water (NI) Order (Published jointly by the $\mathrm{DoE}(\mathrm{NI})$ and DANI), at $\mathrm{p} 2$. For further guidance on the scope of this concept, see: The Better Regulation Guide, Cabinet Office, Regulatory Impact Unit, August 1998; and Modernising Government, (1999) Cm 4310.

83 In this regard, see: Proposed Amendments to the Water Resources Act 1991 and the Reservoirs Act 1975: Joint Consultation Paper (Water Directorate, DoE(GB) and the Environment Division of the Welsh Office: October, 1993).

84 Sustainable Development: Opportunities for Change - A Consultation Paper on a Revised United Kingdom Strategy DETR 1998,

http://www.environment.detr.gov.UnitedKingdom/sustainableconsult1/inde. htm. 
development to the effect that regulation would continue to be essential to the achievement of sustainability, particularly in setting standards which protect human health and the natural environment. ${ }^{85}$ However, this document also introduced the objective of "better regulation" - defined as regulation which "delivers objectives without imposing unnecessary burdens." 86 The Government stated that "where regulations exist, we need to consider whether they are too narrowly focused on a single objective and ignore wider economic, environmental and social goals". ${ }^{87}$ In May 1999 the Government published A Better Quality of Life: A Strategy for Sustainable Development in the United Kingdom ${ }^{88}$ which reiterated its commitment to ensuring that where regulation is used, it will comply with the Government's principles of better regulation. These principles were expressed as requiring regulation that is "targeted at the problem in hand; clear and simple to understand; applied consistently, proportionate to the problem and the circumstances of individual businesses, voluntary groups and others; enforced effectively and constructively by the body accountable for its conduct". ${ }^{89}$

The policy of better regulation has informed a raft of new provisions in the context of the discharge consent system. Of particular relevance in this regard are the new provisions governing the application procedure for consents and the Department's considerably expanded powers to monitor and review consented discharges. Some of these provisions continue the contemporary policy emphasis on inclusiveness and greater environmental protection by ensuring greater public consultation and the imposition of more stringent controls on consent holders, while others take account of the wider economic needs of consent holders, particularly the need for stability and clarity. However, the consistent impact of this policy is to streamline and simplify the controls imposed on the application procedure and the review powers which considerably clarifies the legal position of the applicant, the consent holder and the DoE(NI). Each of these changes will now be addressed in turn.

\section{(i) New Provisions Governing the Application Procedure}

One of the most obvious improvements introduced by the Water Order is the decision to place all the specific provisions governing applications for discharge consents and the procedures relating to review, revocation, modification and appeals and so forth into a schedule to the Order..$^{90}$ As is the case under the Water Resources Act 1991, which governs the consent system in England and Wales, this practice considerably clarifies the text of the legislation. However, the changes do not stop there. To begin with, all applications for discharge consent must now be made on the form provided by the $\operatorname{DoE}(\mathrm{NI}) .{ }^{91}$ Where an application (made in compliance with the

85 Sustainable Development: The United Kingdom Strategy, note 2 supra, at Chapter 33, pp 213-214.

86 Opportunities for Change, note 84 supra, at para 85.

87 Ibid.

88 (1999) Cm 4345

89 P 27, para 5.10.

90 Schedule 1.

91 Schedule 1, para 1(1)(a). This requirements also applies to applications for variations made by the holder of the consent - para 7(1). 
requirements laid down in the Order) ${ }^{92}$ is received by the Department, it is now under a statutory duty to consider whether to grant or refuse the consent, or grant it subject to conditions. ${ }^{93}$ In recognition of the increased complexity of the legislative framework governing water pollution and water quality, the Order extends the period within which the Department must make its decision from three to four months. ${ }^{94}$ Not before time, the Order also reverses the default position in the event that a decision is not made within four months. Whereas failure in England and Wales to make a decision on an application for a consent within the statutory period has, for decades, meant that the application is deemed to be refused ${ }^{95}$ in Northern Ireland, the reverse has been the case. Under section 9(5) of the Water Act (NI) 1972 Act, if the Department failed to make a decision on an application within the statutory period of three months, an unconditional discharge consent was granted by default. Fortunately, the Water Order reverses this arcane emphasis on the primacy of economic interests. Hence, in the absence of a decision by the $\operatorname{DoE}(\mathrm{NI})$ within the statutory period, an application will be deemed to have been refused. It is, however, interesting to note that although the Review of the Water Act (NI) 1972 recommended extending the decision-making period from three to four months, ${ }^{96}$ it suggested that the application "would take its normal course" in the event that no decision was taken within the statutory time limit. ${ }^{97}$ One can only wonder that the DoE(NI) was prepared to persist with this clearly anomalous approach to pollution control as recently as 1993 . One further environmental safeguard introduced by the Order in this context is the removal of the applicant's immunity from prosecution for discharges made pending the outcome of an application for consent. Under section 9(11) of the 1972 Act a person was not guilty of a water pollution offence if they had made an application for a discharge consent and the discharge made complied with the description of the discharge contained in the application. This immunity from prosecution lasted for the three months allotted to the Department to consider the application.

The Order also increases and clarifies the DoE(NI)'s powers to obtain the information necessary to determine the application. As was the case under section 9(1) of the 1972 Act, applicants must provide such information as

92 Or any requirements laid down in regulations adopted by the $\operatorname{DoE}(\mathrm{NI})$ under Schedule 1, para 1

93 Schedule 2(1).

94 Thereby bringing Northern Ireland into line with the position in England and Wales (Schedule 10, para 3(2) WRA 1991). The 4-month time limit also applies to deciding applications to vary a consent (para 7). As is the case under the WRA 1991, the DoE(NI) retains the power to extend this period either by regulation or with the (written) agreement of individual applicants. In the event that a public inquiry is directed (either jointly with PAC or not), the time limit for making a decision on a discharge consent application will cease to apply. This reform implements recommendation 5.3 of the Review of the Water Act (NI) 1972: A Consultation Paper, December 1993 (DoE(NI) and Department of Agriculture (NI)).

95 This has been the consistent position in England and Wales since the adoption of COPA 1974

96 Note 94 supra, at para 5.3.2.

97 Ibid. 
may be required by the DoE(NI) either on, or together with, their application form..$^{98}$ However the Department is also given a new power to serve a notice on the applicant requiring the provision of "further information of any description" that may be necessary for the purposes of determining the application. In addition, the penalty for knowingly or recklessly providing information that is false in a material particular for the purpose of obtaining a discharge consent is increased from $£ 500$ to the statutory maximum of $£ 5,000$ for summary conviction; 99 the alternative penalty of three months imprisonment is retained. The penalty for conviction on indictment remains at an unlimited fine and/or a maximum sentence of 2 years. It should be noted that while failure to provide the necessary information to support an application will not invalidate an application, ${ }^{100}$ failure to comply with advertising requirements or requirements concerning the provision of information, entitles the $\operatorname{DoE}(\mathrm{NI})$ to refuse to proceed with the application either entirely or until the relevant requirements have been complied with Schedule 1 also makes it clear that an application to discharge at two or more places may be treated as separate applications for each discharge. ${ }^{101}$

One important problem that emerged in the operation of the discharge consent system under the Control of Pollution Act 1974 (COPA) and Water Act (NI) 1972 concerned the absence of control over discharges of new pollutants. New pollutants included substances that were either added to the discharge after the consent had been obtained, or were incapable of being traced when the consent was issued, or were identified as having a polluting effect after the consent was issued. William Howarth pointed out that controlling new pollutants under COPA 1974 was extremely difficult due to the proliferation of new industrial chemicals and the absence of a general duty imposed on consent holders to inform the regulator of changes in the composition of the discharge. ${ }^{102}$ Even where new pollutants were identified, regulators were very restricted in their opportunities to review discharge consents. ${ }^{103}$ Under COPA a Regional Water Authority could not review a discharge consent within two years of it being granted without the agreement of the discharger. In Northern Ireland, the Water (NI) Act 1972 afforded the holders of discharge consents a further year of immunity from review. Consequently, provided they complied with the conditions of their consents, unco-operative dischargers could continue to emit pollutants not covered by their consent for several years. This loophole was closed in England and Wales under the Water Resources Act 1991 and eight years later in Northern Ireland by the Water (NI) Order 1999. Both measures provide that it is not an offence to discharge or deposit any effluent or matter made "under and in accordance with" a discharge consent. Similarly it is not an offence to discharge or deposit any effluent or matter as a result of any act or omission "under and in accordance with" a discharge consent. ${ }^{104}$ In legislative terms,

98 Schedule 1, para 1(3).

99 Article 29.

${ }^{100}$ Para 1(4).

${ }^{101}$ Schedule 1, para 1(5).

102 Howarth, "Water Pollution: Improving the Legal Controls" (1989) 1 Journal of Environmental Law at pp 28-29.

103 Ibid.

104 Section 88 of the WRA 1991 and article 10 of the Water (NI) Order 1999. 
this amendment goes some way to conveying the message that a discharge consent is not a licence to pollute. To clarify the matter further, the Environment Agency has recommended that all consents should include a general condition that excludes the discharge of any substance not specifically identified in the discharge consent. It is hoped that the $\operatorname{DoE}(\mathrm{NI})$ will adopt a similar practice in Northern Ireland. There is, however, a remaining weakness in the controls available in relation to new pollutants. This weakness is present in the WRA 1991 and has been carried over into the terms of the Northern Ireland Order. Although a discharge must be made "under and in accordance with" the terms of the consent, the Department does not have the power to vary a consent solely on the grounds that a discharge is being made in breach of the consent, ${ }^{105}$ nor does it have the power to vary the consent for the purposes of addressing the presence of a new pollutant. ${ }^{106}$ Unless the new pollutant is caught under new EC or international law, the Department cannot review a consent for at least four years. Alternatively, the Department could attempt to vary the consent within this period on the grounds of public health or protection of flora and fauna dependent on an aquatic environment. However, as will be discussed below, strict rules govern the Department's powers in this regard and there is a potential liability to compensate the holder of the consent for loss incurred as a result.

\section{(ii) Consents Granted Without Applications}

The DoE(NI)'s powers to regularise illegal discharges have also been extended to come into line with the equivalent powers conferred on the Environment Agency. ${ }^{107}$ Under the 1972 Act the Department's powers in this respect were limited to granting a consent where an unlawful discharge had already occurred. However, Schedule 1, paragraph 4(1) of the Order also enables the Department to act in a preventative manner by extending this power to include situations where an unlawful discharge is likely to occur. ${ }^{108}$ As was the case under the 1972 Act, polluters are not granted immunity for offences committed before the consent is granted under paragraph 4. ${ }^{109}$ A particularly interesting feature of the Department's powers in this regard concerns the requirements for public consultation. Whereas the 1972 Act was silent as to whether notice of a consent issued without an application should be published, the 1999 Order imposes very specific and stringent requirements concerning public consultation on the granting of such consent. ${ }^{110}$ Indeed, these requirements provide consultation guarantees that are not afforded to the public where the $\operatorname{DoE}(\mathrm{NI})$ receives an application for a discharge consent. The Department must publish notice of a consent issued under paragraph 4 . There is no provision made for dispensing with this

105 Bell, note 3 supra at $\mathrm{p} 460$.

106 Ibid.

107 These are contained in Schedule 10, para 6 to the WRA 1991.

108 Where the DoE(NI) grants a consent under paragraph 4, notice of this decision must be served on the relevant fisheries body (para 4(2)). It should also be noted that the $\operatorname{DoE}(\mathrm{NI})$ retains its powers to attach appropriate conditions to a consent issued under paragraph 4.

109 Para 4(3).

110 The public consultation requirements are identical to those applying in England and Wales under Schedule 10, para 6 to the WRA 1991. 
requirement and, consistent with the polluter pays principle, the cost of advertising the consent can be recovered from the polluter. ${ }^{111}$ In addition, the Department must send copies of the consent to such persons as may be prescribed. ${ }^{112}$ Furthermore, paragraph 4 places the Department under a statutory duty to consider any representations made in relation to this consent and confers powers to prescribe a statutory period within which such representations should be made. Under normal circumstances, once a discharge consent has been granted it is immune from revocation or review for at least four years unless with the holder's consent. However, paragraph 6(4) provides that this restriction will not apply to a consent issued under paragraph 4. If the Department considers it appropriate to modify or revoke the consent in light of representations received, and notice of this decision is served within three months of the period to be prescribed for making representations in this context, the consent may be revoked or modified. Consequently, although public consultation takes place after the consent has been granted, it is a meaningful process. The effectiveness of public consultation in relation to paragraph 4 consents depends ultimately on the $\operatorname{DoE}(\mathrm{NI})$ 's ability to ensure that a notice of its intention to alter or revoke the consent is issued within the three month time limit. Whereas failure on the part of the DoE(NI) to make a decision in relation to an application for a discharge consent simply means that the application is refused, failure to issue a notice reviewing or revoking a paragraph 4 consent effectively renders it immune from review for at least four years. ${ }^{113}$ Hence, on the one hand, the Order denies the regulator the benefit of the extended period given for considering applications for discharge consents, while on the other hand it permits polluters, who have failed to apply for a consent and may be guilty of a pollution offence, to rely on the extended period of immunity from review granted to those who have applied for their consent before making a discharge. Given that the issues surrounding a discharge made under a paragraph 4 consent may be no less complex than those made under normal consents, this imbalance is unfortunate to say the least.

\section{(iii) The Power to Review a Discharge Consent}

As was the case under the Water Act (NI) 1972, the Water Order confers powers on the $\operatorname{DoE}(\mathrm{NI})$ to review discharge consents periodically; however, under the new legislation these powers are considerably strengthened. The DoE(NI)'s powers to review discharge consents are now identical to those available to the Environment Agency under the WRA 1991. The most important change in the Department's power to review is that discharge consents are no longer immune from revocation. Under the 1972 Act, provided a consent was being used (that is, a discharge was being made), a consent could only be varied. ${ }^{114}$ Although it could restrict the nature or scale

111 Schedule 1, para 4(7).

112 Para 4(5).

113 Subject to the DoE(NI)'s general powers to review at any time for the purposes of ensuring compliance with EC and international law, or to protect public health, or flora and fauna dependant on an aquatic environment. The Department's powers in this respect are discussed below. It should be further noted that, as is the case for consents issued in response to an application, the holder of a para 4 consent may apply at any time for a variation of the consent - para 6(5).

114 Section 10(2). 
of a discharge by varying the conditions attached to the consent or by imposing new conditions, the Department did not have the power to revoke the consent entirely. Not before time, the 1999 Order remedies this fundamental weakness in the regulatory system. Schedule 1, paragraph 5 of the Order now gives the Department power to conduct periodic reviews that may result in the revocation or modification of a consent, or the imposition of conditions on a previously unconditional consent. ${ }^{115}$ Although recommended in the Consultation Paper, ${ }^{116}$ the Order does not oblige the Department to advertise its intention to conduct a review. Given that a review may result in a significant change to the consented discharge, and in light of the general thrust towards enhancing public participation in the regulation of water pollution, this omission is an important weakness in the legislation. Public notification of a review will only be required where the discharger actually applies for a variation of the consent. In such situations, the notification and consultation requirements governing an initial application for a consent will apply. ${ }^{117}$ The weakness in public consultation is further compounded by the fact that the Order does not explicitly require the Department to record the conduct and outcome of reviews on the public register maintained under article 30.

As was the case under the 1972 Act, the Department's power to conduct a review is entirely discretionary. There are however, some important limitations imposed on the exercise of this power. Prior to the enactment of the Water Order, consents were immune from modification for at least three years - in contrast to dischargers in England and Wales who were, until 1996, only allowed a two-year period of immunity from review. ${ }^{118}$ In Northern Ireland, as in England and Wales, this period has now been extended to four years. ${ }^{119}$ Although some would argue that reviews should be carried out more rather than less frequently, the Consultation Paper recommended this change in the interests of providing greater stability for dischargers and therefore more security in investment and planning. It is at least welcome that dischargers in Northern Ireland are no longer afforded a longer period of immunity than their counterparts in England and Wales. In the interests of better regulation, every discharge consent must specify the period during which the consent cannot be modified or subject to new conditions without the agreement of the discharger. ${ }^{120}$ One interesting exception to the four-year

115 The Department's power in this regard are identical to those conferred on the Environment Agency under Schedule 10, para 7(2) of the WRA 1991.

116 Note 94 supra, at para 5.5.1.

117 Schedule 1, para 7(2).

118 This was the original position under COPA 1974, which persisted until recently under the Schedule 10, para 7(3) of the WRA 1991.

119 Schedule 1, para 6(3) of the Water (NI) Order 1999. In England and Wales the statutory period of immunity was increased to four years by the Environment Act 1995 (section 120, Schedule 22, para 183), which came into effect in 1996 under the Environmental Act 1995 (Commencement No.8 and Saving Provisions) Order 1996 SI 1996/2909.

120 Consent holders now have a new right under article 13(1)(e) to appeal a decision by the Department to specify a period of less than four years without the holder's consent. The requirement concerning the specification of the review period also applies to a consent that has been modified as a result of a previous review Schedule. 1, para 6(2). It is interesting to note, however, that the Department is 
rule concerns the Department's power to revoke a consent. Although the $\operatorname{DoE}(\mathrm{NI})$ is not conferred with the general power conferred on the Secretary of State in England and Wales to direct that a review be undertaken at any time, the Department's power to revoke a consent does not appear to be subject to the four-year rule. ${ }^{121}$ The Order also shortens the potential 'life' of a discharge consent. Under the 1972 Act, a discharge consent had a minimum life of three years; however, the $\operatorname{DoE}(\mathrm{NI})$ now has the right to revoke any consent that has not been used at any time during the previous year. Given its general power to revoke, this power is somewhat superfluous.

In addition to its general power to review discharge consents every four years, Schedule 1, paragraph 5(4) gives the Department new powers to review consents at any time in specific circumstances. Paragraph 5(4) provides that the $\operatorname{DoE}(\mathrm{NI})$ may review a consent (leading to revocation, modification or the imposition of conditions) at any time, if it appears that it is necessary either: (a) to implement any of the United Kingdom's EC or international law obligations or (b) to protect public health or flora and fauna that is dependent on an aquatic environment. ${ }^{122}$ Before proceeding to address the nature and scope of these new powers, it is important to emphasise, that the $\operatorname{DoE}(\mathrm{NI})$, like the Environment Agency, is not given power to vary a consent prematurely purely on the grounds that the discharge does not comply with the terms of the consent. ${ }^{123}$

Although the DoE(NI)'s new power to review a consent at any time to ensure compliance with EC and international law is undoubtedly welcome, it is disappointing, particularly in relation to compliance with EC environmental law, that the decision to review for these purposes is left to the DoE(NI)'s discretion - particularly given the Department's poor record in implementing EC Directives on the environment. ${ }^{124}$ It is likely, however, that the Northern Ireland Act $1998^{125}$ - if revived - would remedy this weakness. Section 24(1)(b) of the Northern Ireland Act provides that "a Minister or Northern Ireland department has no power to make, confirm or approve any subordinate legislation, or to do any act" which is incompatible with EC law. Although section 24 does not define the meaning of an 'act' in this context or explain whether a failure to act would come within its ambit, it is certainly arguable that a failure to act that is incompatible with EC law would amount to a breach of section 24(1)(b). In effect, if EC law prohibits certain types of discharges to freshwater bodies, and the $\operatorname{DoE}(\mathrm{NI})$ has issued a consent that allows an illegal discharge to be made, then it can be argued that a failure on the part of the DoE(NI) to review the consent to bring it into line with EC law, would amount to an act that is incompatible with EC law under section

not obliged to provide the holder with specific notification of its intention to review after than period has expired.

121 Schedule 1, para 6(1) and (2).

122 This power is identical to the power given to the Environment Agency under Schedule 10, paragraph 7 of the WRA 1991.

123 Bell, note 3 supra at $\mathrm{p} 460$.

124 S. Turner \& K. Morrow, "The Impact of EU Law on the Environmental Law of Northern Ireland", in Holder (ed) The Impact of EU Environmental Law in the United Kingdom, Wiley (1997), pp 69-84.

125 c. 47 . The terms of the 1998 Act were suspended under the Northern Ireland Act 2000, see infra. 
24(1)(b). In addition, legal developments at both national and EC level are likely to provide strong incentives to the $\operatorname{DoE}(\mathrm{NI})$ to ensure practical compliance with EC law. In 1992 the Maastricht Treaty amended the EC Treaty to confer power on the European Commission to recommend to the European Court of Justice the imposition of financial penalties on Member States who fail to comply with a Court judgment declaring that they are in breach of their Community obligations. ${ }^{126}$ The Commission declared its intention in 1996 to focus its enforcement activities on the specific issue of ensuring Member States' compliance with EC environmental law, monitoring in particular their compliance in practice as opposed to purely formal implementation. ${ }^{127}$ In addition, the past decade has witnessed the European Court's rapid development of a principle of state liability under which Member States may be held liable to compensate private parties who have sustained injury or loss as a result of a State's failure to comply with its obligations under EC law. ${ }^{128}$ Hence, non-compliance with EC environmental law is not only likely to attract enforcement action from the European Commission, Member States also face the possibility of simultaneous actions in damages before their national courts if loss or injury is sustained by private parties as a result of their failure. The Concordat on Co-Ordination of European Union Policy Issues ${ }^{129}$ governing relations between the United Kingdom Government, the Scottish Parliament and the National Assembly for Wales states that financial costs and penalties imposed on the United Kingdom arising from a failure of implementation or enforcement of EC law by a devolved administration (on a matter falling within its responsibility) will be paid by the devolved administration. While an equivalent Concordat has not yet been published for the Northern Ireland Assembly, it is likely that similar arrangements would be agreed following the restoration of devolution. Given that responsibility for almost all matters concerning the environment are transferred to the Northern Ireland Assembly under the Northern Ireland Act 1998, the revival of devolution would mean that the financial impact of non-compliance with EC environmental law would be felt more immediately by the $\operatorname{DoE}(\mathrm{NI})$ than has previously been the case.

The Department's new powers to review a consent at any time in the interests of protecting public health or flora and fauna dependent on an

126 Article 171EC (now renumbered article 228 EC under the Treaty of Amsterdam).

127 Implementing Community Environmental Law $\operatorname{COM}(96) 500$ final. For further discussion of the European Commission's use of its enforcement powers in the context of environmental law, see: Macrory and Purdy, "The Enforcement of EC Environmental Law Against Member States" in Holder (ed.), note 124 supra, pp 27-50; Macrory, "The Enforcement of Community Environmental Laws: Some Critical Issues" (1992) 29 CML Rev pp 347-369

128 The seminal judgments on the principle of state liability under EC law were delivered in Case C-6/90 Francovich v Italian State [1993] 2 CMLR 66; Cases C46/93 and C-48/93 Brasserie du Pêcheur SA v Federal Republic of Germany and $R$ v Secretary of State for Transport, ex parte Factortame ltd (No. 4) [1996] All ER (EC) 301. For discussion of the application of the principle of state liability in the context of environmental law cases, see: Hilson, "Community Rights in Environmental Law: Rhetoric or Reality?", in Holder (ed), note 124 supra, at pp 64-68.

129 (1999) Cm 4444, p 20. It should be noted that the Concordat is not legally binding; it is intended to be binding in honour only. 
aquatic environment also raise a number of interesting issues. On the face of it, these new powers enable a higher level of protection for Northern Ireland's aquatic wildlife and the population in general. In particular, the Department is given the power to respond to emerging scientific data concerning the potential or actual impact of new or existing pollutants on public health or aquatic wildlife. In reality, however, the Government's commitment in this regard is qualified. Paragraph 5(6) provides that where the Department takes action in relation to a discharge consent as a result of a review conducted for the purposes of protecting public health or fauna and flora, the holder of the consent will be compensated for any loss or damage sustained as a result of that action. However, the Department will not be liable to pay compensation if its action in relation to the consent is within the confines of action permitted under paragraph 5(4) and either the action is taken: (a) as a result of a change of circumstances that was not reasonably forseeable when the consent was issued or most recently renewed, or (b) on the basis of material information ${ }^{130}$ which was not reasonably available to the Department when the consent was issued or last renewed.

The conditions laid down in paragraph 5(6) effectively seek to ensure legal certainty, protect property rights and give expression to the principle of legitimate expectation - which in this context dictates that a recent consent will not be changed unless circumstances change markedly. Although it is unclear where the burden of proving the above conditions lies (either with the Department or the person seeking compensation, or both), they will undoubtedly operate as a 'double-edged sword'. On the one hand, they will ensure that compensation is paid only in strictly defined circumstances. However, on the other hand, to avail of its new powers of review, the Department must ensure that it acts within the confines of powers under paragraph 5(4), and also that the potential impact of discharges on public health and aquatic organisms are considered as fully as is reasonably possible when making the initial decision to grant a discharge consent. In particular, the Department must ensure that it is as up-to-date as is reasonably possible on the scientific data concerning the impact of discharges (acting alone, or in combination with other discharges or other matter) on health and wildlife that are dependant on an aquatic environment. In effect, the availability of these powers, depends ultimately on the DoE(NI)'s capacity to consider the full environmental impact of each application for a discharge consent.

\section{(iv) The Transfer of Consents}

Consistent with the principle of better regulation and in line with provisions governing discharge consents in Great Britain, ${ }^{131}$ the Water (NI) Order 1999 introduces new controls on the transfer of a consent granted by the DoE(NI). The objective of these new provisions is to ensure a seamless transfer of responsibility for the discharge. A discharge consent will be considered to be part of the holder's personal estate in the event that the holder dies and will therefore vest in his or her personal representatives. In the event of a

130 Information is defined as being "material" in relation to a discharge consent, if "it relates to any discharge made or to be made by virtue of the consent, to the interaction of any such discharge with any other discharge or to the combined effect of any matter discharged and any other matter".

131 Schedule 10, para 11 of the WRA 1991. 
bankruptcy order against the holder, the consent will be regarded as forming part of the bankrupt's estate and will vest as such in the trustee of the bankruptcy. Neither the holder of a consent, nor the holder's personal representatives or bankruptcy trustee may disclaim the consent. The holder of a discharge consent may transfer the consent to a person who intends to carry on the discharge in place of the holder. ${ }^{132}$ Where a consent is transferred to another holder, or vests under paragraph 8 personal representatives or trustee, the consent will take effect on and after the date of the transfer or vesting as if it had been granted to that person; the same conditions governing the discharge will apply. The Order also imposes strict rules requiring notification to the $\operatorname{DoE}(\mathrm{NI})$ of the fact of a vesting or transfer. The person from whom the consent transferred must notify the Department of the transfer within twenty-one days of the beginning of the transfer, whereas a vesting must be notified to the $\operatorname{DoE}(\mathrm{NI})$ within fifteen months of the date on which the vesting began, by the person in whom the consent vested. A failure to notify a vesting of the consent within the time period will result in the consent ceasing to have effect. A failure to comply with the notification requirements is an offence; the penalty on summary conviction is a maximum fine of $£ 5,000$ and for conviction on indictment, an unlimited fine and/or imprisonment for a maximum of two years.

\section{(v) The Sampling of Discharges}

Another area of significant improvement in the pollution control powers conferred under the Water Order concern the Department's powers to obtain samples of water and effluent that are admissible as evidence in legal proceedings. Although not limited to the regulation of discharge consents, these new powers will considerably enhance the Department's ability to enforce consents effectively. As was the case under section 209 of the Water Resources Act 1991, the Water Act (NI) 1972 provided that, in order to be admissible as evidence in a prosecution, samples must comply with the traditional tripartite sampling regime. ${ }^{133}$ The tripartite rule required the $\operatorname{DoE}(\mathrm{NI})$ to notify the occupier of the land in question of its intention to have the sample analysed and, there and then, to divide the sample into three parts - one of which was sent for analysis, one of which was given to the occupier and one which was retained for future comparison. In addition, the Court of Appeal in CPC (United Kingdom) Limited v National Rivers Authority ${ }^{134}$ ruled that samples taken by automatic continuous water monitors were inadmissible thereby requiring the regulator to base prosecutions for water pollution offences on samples that had been obtained manually. ${ }^{135}$ Aside from the practical inconvenience involved in obtaining manual samples, taking a tripartite sample cost five times as much as a routine sample. ${ }^{136}$ The Environment Act 1995 resolved the problem in England and Wales by repealing section 209, although this change was vigorously opposed by

132 Para 8

133 Section 25(5).

134 [1995] Env LR 131

135 In effect, the Court ruled that samples must be physically separated and isolated from the body of water and placed in a container. For a general discussion of the tripartite rule see: Hughes, note 60 supra at pp 576-577.

136 Bell, Ball \& Bell on Environmental Law, (4 ${ }^{\text {th }}$ ed, 1997) at p 469. 
industry. ${ }^{137}$ Section 111 of the Environment Act 1995 now simply provides that information provided or obtained pursuant to a consent condition is admissible, including information provided or obtained or recorded by means of "any apparatus" - this apparatus is also presumed to be accurate unless the contrary is shown. ${ }^{138}$ Consequently, the Act dispensed with both the cumbersome tripartite regime and the need to 'take' samples manually. Although the difficulties associated with the tripartite sampling rule had been the subject of considerable criticism in England and Wales prior to the adoption of the Environment Act 1995, the 1993 Review of the Water Act (NI) 1972 did not address the equivalent weakness in the $\operatorname{DoE}(\mathrm{NI})$ 's sampling powers under the Act. Instead the Consultation Paper focused on the problem of applying the tripartite regime to the taking of composite samples under the EC Urban Waste Water Treatment Directive 91/271. ${ }^{139}$ Once again the delayed adoption of the Water (NI) Order 1999 produced a beneficial effect in that the Order, as finally made, does remedy this weakness in the DoE(NI)'s sampling powers. Article 27 brings Northern Ireland into line with the position under the Environment Act 1995 and includes the rebuttable presumption that the apparatus is accurate. In effect, article 27 will enable the Department to use automatic sampling machines to provide 'legal' samples and reduce the likelihood that polluters will evade liability as a result of evidential technicalities. ${ }^{140}$

\section{(vi) Powers of Entry and Inspection}

Article 25 of the Water Order considerably increases the DoE(NI)'s powers to enter and inspect premises for the purpose of exercising its pollution control powers under the Order and ensuring that the terms of the Order are being complied with. Unfortunately, however, this is one area where the changes wrought do not give the Department the very wide powers available to the Environment Agency under section 108 of the Environment Act 1995. One of the most important improvements in the Department's powers in this respect is the extension of the term premises to include "mobile plant", which includes fish cages. ${ }^{141}$ Although aquaculture in Northern Ireland is currently under-developed when compared to the Republic of Ireland, this is

137 Ibid, at $\mathrm{p} 470$.

138 Section 111(3).

139 OJ L135, 30 May 1991. Composite samples involve sampling over a 24-hour period, bulking the 24 parts and analysing the composite sample - hence sampling by an individual officer would be time-consuming and expensive. See also the Review of the Water Act (NI) 1972: A Consultation Paper (December 1993, DoE(NI) and DANI) at pp 13, para 7.1.

140 The definition of "apparatus" contained in Article 3(1) of the Water Order is identical to the definition contained in section 111(5) of the EA 1995. A number of automatic sampling devices have been developed for continuous monitoring. For a description of 'Merlin', 'Sherlock' and 'Cyclops' see: Mumma, "Use of Compliance Monitoring Data in Water Prosecutions" (1993) 3 Journal of Environmental Law 19.

141 Article 25. The Order does not provide a direct definition of the term "premises"; however article 25(5) includes mobile plant in the definition of premises that may be entered and the explanatory document accompanying the Order highlights mobile plant as being included in the definition. Mobile plant is defined in article $3(1)$ as meaning plant which is designed to move or be moved whether by road or otherwise. 
an industry that is likely to expand considerably in the future. ${ }^{142}$ Another important change is the extension of the Department's powers of inspection from simply "inspecting and surveying" under the $1972 \mathrm{Act}^{143}$ to include measuring, testing and taking away samples of water, effluent, land or articles. $^{144}$ In doing so, the Order brings the DoE(NI)'s inspection powers broadly into line with the Environment Agency's powers, but there are also regrettable gaps in the Department's powers in this regard. In particular, the DoE(NI), unlike the Environment Agency, is not explicitly conferred with the power to take photographs, nor is it given the power to take samples of air and substances. Although the Order gives the DoE(NI)'s new powers to install to and keep monitoring or other apparatus on a premises, to fix sampling points and to carry out experimental borings or other works on the premises, this reform is somewhat half-hearted. Unlike the Environment Agency, the Department is not given power to direct that any premises it has entered or anything in them must be left undisturbed for so long as is necessary to conduct the examination or investigation. It goes without saying that this omission may limit to a considerable degree the Department's ability to use its new powers. Similarly, the DoE(NI), unlike the Agency, is not given power to take, dismantle, damage or destroy an article or substance found on a premises which is likely to cause pollution to the environment or harm to human health. Furthermore, the Department is not given the important powers granted to the Agency to require the provision of facilities and assistance with respect to matters or things within another person's control that is necessary to exercise the powers of entry and inspection. Nor is the Department conferred with the Agency's power to require any person who may be able to provide information relevant to the investigation to answer questions and to sign a declaration testifying to the truth of their answers. Last, but not least, the Water Order fails to bring the DoE(NI)'s emergency powers into line with those conferred on the Environment Agency. Whereas the Agency may make a forced entry at any time in cases of emergency, the Department must obtain a warrant to enter, and strangely, is only empowered to enter at a reasonable hour.

\section{SECTION II}

\section{AN AGENDA FOR FURTHER REFORM}

The analysis thus far of the Water (NI) Order 1999 makes clear that this new legislation represents an important, albeit overdue, milestone in the modernisation of water pollution law and policy in Northern Ireland. When it comes into force, the core legislative framework governing water pollution control will implement principles and policies that are now considered to be fundamental to contemporary national and EC environmental law. However, although Northern Ireland is on the verge of gaining the means by which to

142 See generally, Northern Ireland Aquaculture Development, October 1995: Study Commissioned by Northern Ireland Seafood. See also the following publications produced by the Irish Sea Fisheries Board, Seafood Industry Agenda 2000-2006: Realising the Regional Potential of the Irish Seafood Industry (March 1999) and Aquaculture and the Environment.

143 Section 23(1).

144 Article 25(2)(b). 
afford a high level of legal protection to its aquatic environment, the process of modernisation is far from complete.

Despite being totally at odds with national and EC policy on pollution control, the Water (NI) Order 1999 makes no attempt to resolve the poachergamekeeper conflict that continues to undermine the DoE(NI)'s credibility as regulator in the field of water pollution. In addition, significant disparities remain in the level of protection afforded to the freshwater environment in Northern Ireland and that extended to its counterparts in England and Wales. Although parity with England and Wales may become less important as a result of devolution in the field of environmental protection, a decision to tolerate weaker standards in this jurisdiction may guarantee Northern Ireland's future as a pollution haven within the United Kingdom. To compound these problems the Northern Ireland Comptroller and Auditor General has recently reported a series of fundamental shortcomings in the DoE(NI)'s administration and enforcement of the existing statutory framework governing the aquatic environment in Northern Ireland. ${ }^{145}$ The Auditor General's highly critical report documents a scene of almost endemic regulatory failure thus raising serious concerns as to the Department's ability to engage with the more rigorous controls introduced by the new Water Order. Last, but not least, there is a failure to grapple with the forthcoming tidal wave of reform in the field of EC water law. The European Union is currently preparing to enact a new Water Framework Directive, ${ }^{146}$ which represents a thorough restructuring of EU policy on the aquatic environment and will set objectives for water protection well into the next century. Although the adoption of the Water (NI) Order 1999 provided an ideal opportunity to lay the foundations for implementing the terms of this Directive in Northern Ireland, little effort was made to anticipate the demands of this new phase of reform.

In December 1999 legislative and executive powers were devolved to the Northern Ireland Assembly under the Northern Ireland Act 1998. ${ }^{147}$ With only two exceptions, ${ }^{148}$ all responsibility for environmental protection was devolved to the Assembly, including power to make law and policy on the issue of water pollution subject of course to the proviso the it must act in accordance with international and EC law. ${ }^{149}$ Although at the time of writing the legislative and executive powers of the Assembly have been suspended

145 Control of River Pollution in Northern Ireland, Report by the Comptroller and Auditor General for Northern Ireland; HC 693, Session 1997-98.

146 Council Text, The European Union Council, Common Position, 19 February, 1999; Commission Texts, COM(1999) 271 final, COM(97) 49 final, COM(98) 76 final; European Parliament Texts, Parliament's First Reading Amendments A40261/98, $\operatorname{COM}(97) 49$ final, $\operatorname{COM}(98) 76$ final.

147 c.47.

148 Schedule 3, para 39 provides that the subject matter of section 3(5) to (7) of the Environmental Protection Act 1990 (emission limits and quality objectives) and the environmental protection technology scheme for research and development in the United Kingdom are reserved matters. Under section 3 of the EPA 1990, the Secretary of State has the power to make national plans establishing emission limits for the release of any substance into the environment or for the progressive improvement in quality objectives and standards.

149 Section 6 of the Northern Ireland Act 1998 
and the North/South and British-Irish elements have been stalled, ${ }^{150}$ if they are revived the aquatic environment would be the subject of governance through a complex web of structures. First and foremost, responsibility for the aquatic environment will lie with four of the new departments of the Northern Ireland Assembly. Pollution control, and therefore the administration and enforcement of much of the Water Order, will be dealt with by the Department of the Environment. Responsibility for the provision of water falls within the remit of the Department for Regional Development. The development of inland waterways and fisheries will be dealt with by the Department of Culture, Arts and Leisure, while the Department of Agriculture and Rural Development will deal generally with the issue of farming and environmental policy, which will inevitably impact on the freshwater environment. However, it is also worth noting that the aquatic environment could also come within the remit of the Office of the First Minister and Deputy First Minister, for example, as an issue of policy innovation. Each of the new departments will be assisted and advised by a 'statutory committee' with power to play a scrutiny, policy development and consultation role in relation to its department and a role in the initiation and opposition of legislation. ${ }^{151}$ Secondly, the management of the aquatic environment will be the subject of all three tiers of the all-Ireland dimension to Northern Ireland devolution; namely the North/South Ministerial Council, ${ }^{152}$ the cross-border implementation bodies ${ }^{153}$ and the (initial) six areas identified for co-operation between existing government structures, North and South. ${ }^{154}$ Thirdly, the environment comes within the remit of the British-Irish Council established to promote the harmonious and mutually beneficial development of relationships among the peoples of the United Kingdom and Ireland. ${ }^{155}$ The British-Irish Council will exchange

150 Devolution was suspended with effect from 12 February 2000 by the Northern Ireland Act 2000, c. 1.

151 The system of statutory committees (as envisaged by Strand 1, para 9 of the Belfast Agreement) was established under section 29 of the Northern Ireland Act 1998.

152 Strand 2, paragraph 1 of the Belfast Agreement refers to the establishment of a North South Ministerial Council designed to bring together Ministers from Northern Ireland and the Irish Government to develop consultation, co-operation and action on an all-island basis on matters of mutual interest. See also section 52 of the Northern Ireland Act 1998. It should be noted that the Government's Memorandum of Understanding and 4 Concordats of October 1999 (Cm 4444) deal, inter alia, with North/ South Council matters.

$153 \mathrm{Six}$ cross-border implementation bodies were established by international agreement between the British and Irish Governments for the purpose of implementing the policies agreed by the Ministers in the North/South Ministerial Council. See: the (Irish) British Irish Agreement Act and the North South Cooperation (Implementation Bodies) (NI) Order 1999 (SI 1999/859). The six bodies came into existence on the 2 December, 1999. Two of the six bodies have a specific role to play in relation to the freshwater environment; namely, Waterways Ireland and The Foyle, Carlingford and Irish Lights Commission.

154 These six (initial) areas of co-operation are in addition to the six Implementation Bodies. The 'environment' is identified as one such area of co-operation, specifically for present purposes, research into environmental protection and water quality management.

155 See sections 52 and 53 of the Northern Act 1998 and Strand 3 of the Belfast Agreement. It should be noted that the Government's Memorandum of 
information, discuss, consult and use best endeavours to reach agreement on matters of mutual interest. ${ }^{156}$ Environmental matters have been identified as one of the priority areas to be addressed by the British-Irish Council. ${ }^{157}$ Because primary responsibility for parliamentary scrutiny in devolved matters passes to the Assembly under the Northern Ireland Act $1998,{ }^{158}$ it is unlikely that independent scrutiny of the Assembly in the field of water pollution control will come in the form of another House of Commons Select Committee Report such as the seminal 'Rossi Report' in 1990 which was largely comprised of MPs external to Northern Ireland. ${ }^{159}$ Similarly, with EC policy on water pollution shifting from its traditionally rigid approach to control towards the conferral of greater discretion to Member States in the implementation of water Directives, ${ }^{160}$ the Assembly and its departments will have more freedom in tailoring the transposition of Directives to the specific conditions pertaining in Northern Ireland. Consequently, if devolution in the form outlined above is revived, much more responsibility will be given to the local political framework to have the will and the confidence to recognise the shortcomings still latent in the regulatory system governing water pollution, the weaknesses of self-regulation and the need for independent scrutiny.

The purpose of Section II of this article is to set out an agenda for further reform of the regulatory framework governing pollution of the freshwater environment in Northern Ireland. Although at the time of writing devolution has been suspended, regrettably the same cannot be said of the need for further reform in this field. While it is possible that the devolution arrangements laid down in the Northern Ireland Act 1998 may remain suspended for an indefinite period, the process of economic regeneration will continue as long as the ceasefires hold. However, to have any hope of ensuring that economic regeneration occurs in concert with - not at the expense of - the effective protection of the freshwater environment, it is vital that immediate steps are taken to address the remaining weaknesses underlying the system of regulation governing water pollution. Indeed, even if the political situation destabilises and political violence re-emerges, the process of reform in the field of water pollution control must not be suspended. As the House of Commons Select Committee on the Environment stated in their 1990 report on Environmental Issues in Northern

Understanding and 4 Concordats of October 1999, note 129 supra, deal, inter alia, with British Irish Council matters. The British-Irish Council will be comprised of representatives of the British and Irish Governments, of the devolved institutions of Northern Ireland, Scotland and Wales and of the Isle of Man and the Channel Islands.

156 Devolving Power to the People of Northern Ireland, Executive Information Service of the Office of the First Minister and Deputy First Minister.

157 Ibid.

158 Northern Ireland Affairs, First Special Report; HC 178, Session 2000.

159 Environmental Issues in Northern Ireland, HC 39, Session 1990-91. The Report became known as the 'Rossi Report' after its chairman, Sir Hugh Rossi. The Report had a fundamental impact on the modernisation of environmental law in Northern Ireland; its findings and their effect in the field of water pollution laws are addressed in Part I of this article, (2000) 51 NILQ 65 et seq.

160 Howarth, "Accommodation without Resolution? Emission Control and Environmental Quality Objectives in the Proposed EC Framework Directive" (1990) 1 Environmental Law Review 6. 
Ireland:161 "the existence of the 'troubles' does not remove the need for dealing effectively with the environmental problems of the Province which are as great as, and in some respects greater than, those of the rest of the United Kingdom."162 If the future of the aquatic environment is to be adequately safeguarded, it is imperative that the Government's commitment to further reform is not contingent upon progress being made in reaching a sustained constitutional settlement. The specific nature and scope of the remaining regulatory problems will now be discussed in more detail.

\section{Resolution of the Poacher-Gamekeeper Dilemma}

The most important shortcoming of the Water (NI) Order 1999 is undoubtedly its failure to resolve the poacher-gamekeeper conflict that has long undermined the DoE(NI)'s role as regulator in the field of water pollution control. As was explained in Part One ${ }^{163}$ of this analysis, the $\mathrm{DoE}(\mathrm{NI})$ is responsible not only for administering and enforcing the system of regulation governing freshwater pollution, ${ }^{164}$ but also for treatment and supply of drinking water and the collection, treatment and disposal of sewage and waste water. ${ }^{165}$ Because the Department's water and sewage treatment works are a source of water pollution, ${ }^{166}$ the $\operatorname{DoE}(\mathrm{NI})$ operates as both the regulator and a polluter of water. Despite the fact that national and European policy on pollution control since 1990 has necessitated the separation of regulatory and operational functions, ${ }^{167}$ and despite the recommendation of the House of Commons Environment Select Committee in 1990 that this conflict of interest be resolved, ${ }^{168}$ the Review of the Water Act (NI) $1972^{169}$ published in 1993 did not address this fundamental issue. Nevertheless, several of the environmental interests groups responding to the consultation paper strongly urged the Government to address this issue as a matter of urgency. ${ }^{170}$ Similarly, members of the Standing Committee on Delegated Legislation expressed considerable concern that the Government had not

161 Note 159 supra.

162 Note 159 supra, at $\mathrm{p}$ vii, para 1.

163 (2000) 51 NILQ, 65 et seq.

164 Under the Water Act (NI) 1972 - this power is exercised by the Environment and Heritage Service (a Next Steps Agency to the Department).

165 Under the Water and Sewerage Services (NI) Order 1973 (SI 1973/70) - this function is exercised by the Water Service (a Next Steps Agency to the Department).

166 Note 145 supra, at Part 4

167 This Common Inheritance: Britain's Environmental Strategy, (1990) Cm 1200, at p 139 para 10.14. See also the discussion of this issue in Part One of this article, (2000) 51 NILQ at 65 et seq.

168 Note 159 supra, at p xxiv, para 78.

169 December 1993 (DoE(NI) and the Department of Agriculture (NI)).

170 Although not all responses to the consultation exercise were made available, the following interest groups strongly urged the Government to separate the DoE(NI)'s regulatory and operational functions: Northern Ireland Environmental Link (on behalf of International Tree Foundation, Lenadoon Environmental Forum, Mountaineering Council of Ireland, Mournes Heritage Trust, Ulster Archaeological Society, Ulster Architectural Heritage Society, Ulster Foundation for the Preservation of the Countryside, Upper Faughan River Trust, and the Wildfowl and Wetlands Trust); Friends of the Earth and The Royal Society for the Protection of Birds. 
used the making of the Order as an opportunity to resolve this fundamental problem. ${ }^{171}$ Whereas in England and Wales the structural and substantive dimensions of the regulatory system were reformed in one fell swoop by the Water Act 1989, in Northern Ireland the Government decided instead to deal with these issues separately and slowly. Having waited a decade to bring the legislation governing water pollution in Northern Ireland broadly into line with that operating in Great Britain, it may be several more years before the structures responsible for delivering water pollution control are finally reformed. In the meantime, the report published by the Northern Ireland Auditor's Office in 1998 concerning the control of river pollution in Northern Ireland raises considerable concerns about the lax standards of control currently applied to discharges from DoE(NI) sewage treatment works. ${ }^{172}$ The report pointed out that the DoE(NI)'s Crown Immunity not only prevented the Environment and Heritage Service (EHS) prosecuting the Water Service for pollution caused by discharges from its sewage treatment works, but also that the standards set by the EHS for such discharges are significantly less stringent than those currently applied by the Environment Agency in England and Wales. Although discharge standards for sewage treatment works in England and Wales were relaxed for a period of time prior to privatisation to enable capital works to be carried out, by 1994 the Government reported a "major, sharp improvement since 1986 in the compliance by sewage works with standards required". ${ }^{173}$ It also reported similar "steady improvement" taking place in Scotland. ${ }^{174}$ In contrast, the Auditor General reported that EHS standards for sewage treatment works in Northern Ireland are currently even more relaxed than the relaxed standards imposed on the Regional Water Authorities in England and Wales prior to privatisation. ${ }^{175}$ Furthermore, it was pointed out that although the data for 1996 indicated that $76 \%$ of treatment works would comply with the standards set by the EHS, the use of these standards for the purposes of public accountability "may be misleading, creating an illusion of compliance with high quality standards, which is not, in fact the case." ${ }^{176}$ In response, the EHS stated that in the absence of the regulatory powers made available in the wake of the separation of regulatory and operational functions in Great Britain, the present regime was as close as possible to the system operating in England and Wales. ${ }^{177}$

Despite the fundamentally weak nature of the control imposed on pollution from $\operatorname{DoE}(\mathrm{NI})$ sewage and water treatment works, the process of addressing the Department's conflicting regulatory and operational roles was only recently launched. In November 1998 the DoE(NI) published Water and Sewerage Services in Northern Ireland: A Consultation Paper, which sets out the Government's proposals for restructuring the provision of water and

171 In particular, Mr Malcolm Moss and Mr Clifford Forsythe raised this issue at length; Third Standing Committee on Delegated Legislation, House of Commons, 2 March 1999.

172 Note 145 supra at pp 47-55.

173 Sustainable Development: The United Kingdom Strategy, (1994) Cm 2426. Chapter 8, at p 62, para 8.38.

174 Ibid.

175 Note 145 supra at pp 49-50.

176 Ibid, p 50 at para 4.24.

177 Ibid. 
sewerage services and the regulatory structure governing the management of water resources in Northern Ireland. Although the DoE(NI) recommended splitting its policing and operational functions, ${ }^{178}$ it is interesting to note that the Consultation Paper characterised this weakness in the regulatory system as perceived rather than real, and as one which necessitated reform in order to increase public confidence rather than ensure compliance with long established national policy on the regulation of water pollution. ${ }^{179}$ In August 1999, the Minister for the Environment (Lord Dubbs) issued a press statement concerning the response to the consultation process. No clear consensus emerged from the process concerning the regulatory structures; however, considerable support was expressed for either an Ombudsman or an independent regulator. ${ }^{180}$ Lord Dubbs reported that officials had been instructed to develop further proposals for reform based on the outcome of the consultation process; however, it was anticipated that the final decision concerning the future of the water industry and regulatory structures would be taken by the Northern Ireland Assembly. Although the Assembly did not address this issue directly during its brief existence, one element of the poacher-gamekeeper problem was temporarily resolved as a result of the allocation of responsibilities amongst the newly established Northern Ireland departments. Whereas responsibility for pollution control remained with the newly created Department of the Environment, responsibility for the functions formerly carried out by the Water Service were re-allocated to the new Department for Regional Development. ${ }^{181}$ Consequently, if the Assembly's devolved powers were restored, the new departmental structures would effectively separate the regulatory and operational functions relating to water. However, the true benefit of this change may be more apparent than real. As a result of its Crown Immunity, the Department for Regional Development could not be brought within the controls of the discharge consent system nor could it be held accountable for any water pollution caused by discharges from its water and sewage treatment works. If Northern Ireland is to have a truly transparent system of water pollution control in which the public can be confident, it is essential that the environmental regulator deciding when and how to enforce is truly independent and has no responsibility for operational functions. Although the DoE would no longer be responsible for operational matters if devolution were revived, as long as the Environment and Heritage Service remains as a Next Steps agency within the Department, it cannot be said to be a truly independent environmental regulator. ${ }^{182}$ In addition, as long as those responsible for water and sewerage services enjoy the protection of Crown Immunity, even the possibility of private prosecutions is ruled out. Consequently, if the aquatic environment in Northern Ireland is to be afforded the level of protection associated with modern standards of

P 14.

179 Ibid, at para 4.7.

180 See also the discussion of the consultation process in the Belfast (Business) Telegraph, Tuesday, August 17, 1999, pp 10.

181 Note 156 supra.

182 The nature of the EHS Next Steps arrangements are discussed in K. Morrow \& S. Turner, "The More Things Change, the More they Stay the Same? Environmental Law, Policy and Funding in Northern Ireland" (1998) Journal of Environmental Law pp 44-46. 
environmental regulation operating elsewhere in the United Kingdom, further reform is essential.

\section{Removal of Continuing Legislative Disparity}

The second major shortcoming of the Water Order is its failure to bring the core legislative framework governing pollution control in Northern Ireland into full parity with that applying in England and Wales. Although a restoration of the Assembly's devolved powers would enable different routes to be taken to ensuring environmental protection, it is submitted that the disparities in question are unjustified and will expose freshwater in Northern Ireland to a greater risk of pollution than elsewhere in the United Kingdom. Each of these shortcomings will be addressed in turn.

\section{(i) The General Obligations Imposed on the DoE(NI)}

Article 4(1), which sets down the DoE(NI)'s general duties under the Water (NI) Order 1999, is without doubt one of the most revealing areas of disparity between the legislation governing water pollution in Northern Ireland and that applying in England and Wales. Article 4(1) provides that the Department shall "promote" both the conservation of Northern Ireland's water resources and the cleanliness of its inland, coastal and ground waters. Article 4(2) goes on to provide that in carrying out its duties in each context, the Department must "have regard to" a series of interests. They are: the needs of industry and agriculture; the protection of fisheries; the protection of public health; the preservation of amenity and the conservation of flora and fauna; and the conservation of geological or physiographical features of special interest and any feature of archaeological, historical, architectural or traditional interest. Except for the addition of the latter interest, the $\mathrm{DoE}(\mathrm{NI})$ 's general duties in relation to pollution control or water resource conservation have remained virtually unchanged despite the far-reaching changes that have occurred in field of water law and policy during the twenty-seven years since the enactment of the Water Act (NI) 1972.

In stark contrast, the statutory aims and duties imposed on the Environment Agency in England and Wales not only make a direct link with the Government's commitment to achieving sustainable development, but also reflect the contemporary policy emphasis on pollution prevention and conservation of nature and the countryside. Section 4 of the Environment Act 1995 states that the "principal aim" of the Environment Agency is to protect or enhance the environment so as to make a contribution towards attaining the objective of sustainable development. Although the Environment and Heritage Service Corporate Plan 1998/2001 states that the Service "aims to be seen as the main protector of the environment in Northern Ireland and a significant influence and lead player in the promotion of sustainable development", the Water Order fails to forge a statutory link between the $\mathrm{DOE}(\mathrm{NI})$ 's pollution control function and its role in promoting sustainability. ${ }^{183}$ Section 5 of the Environment Act 1995 gives explicit

183 Section 33(1) and (2) of the Environment Act 1995 empower the Secretary of State to give guidance to the Scottish Environment Protection Agency concerning the aims and objectives which he considers appropriate for SEPA to pursue in the 
expression to the principle of pollution prevention that is now fundamental to EC and national legislation on pollution control. Under section 5, the Environment Agency is required to exercise its pollution control powers for the purpose of preventing or minimising, or remedying or mitigating the effects of, pollution of the environment. ${ }^{184}$ Although one of the major innovations of the Water (NI) Order 1999 is the conferral of stronger powers to prevent water pollution, the general duties imposed on the $\operatorname{DoE}(\mathrm{NI})$ concerning the exercise of its pollution control powers do not even allude to this considerably expanded dimension of the Department's regulatory function. ${ }^{185}$ By contrast, it is interesting to note that article 40(1) explicitly requires the Department of Agriculture (NI) "to have regard to the prevention of pollution" in the exercise of its functions under the Order concerning inland water navigation and recreation. ${ }^{186}$

Section 6 of the Environment Act 1995 sets out the Environment Agency's general obligations with respect to water. In this regard the Agency is required to promote "to the extent that it considers desirable": (a) the conservation and enhancement of the natural beauty and amenity of inland and coastal waters and the land associated with such waters and (b) the conservation of flora and fauna which are dependant on an aquatic environment. ${ }^{187}$ The Environment Agency is also placed under a general duty to take action to secure "the proper use of water resources". ${ }^{188}$ Although the Northern Ireland Order requires the DoE(NI) to promote the conservation of water resources, the Department is not placed under a specific duty to secure the proper use of water resources in Northern Ireland. ${ }^{189}$ And while the nature conservation duties contained in section 6 are not particularly onerous in that action is only required when the Agency deems it to be desirable, the commitment to conservation is clearly much stronger than that expressed in article 4 of the Water (NI) Order 1999. Whereas the Environment Agency is required to "promote" the conservation and enhancement of the natural beauty and amenity of water and "promote" the conservation of flora and fauna that are dependant on an aquatic environment, the $\operatorname{DoE}(\mathrm{NI})$ is only required to "have regard" to the

performance of its functions. However, any such guidance must include guidance concerning SEPA's contribution towards attaining sustainable development.

184 Similarly, the Scottish Environment Protection Agency is required under section 33(1) of the Environment Act 1995 to exercise its pollution control powers "for the purpose of preventing or minimising, or remedying or mitigating the effects of pollution on the environment."

185 It is interesting to note that the $\operatorname{DoE}(\mathrm{NI})$ is obliged to have regard to the prevention of pollution when exercising its powers under article 23 to (i) carry out engineering or building operations under Part II of the Order; (ii) vary the flow of water or (iii) discharge water into any waterway.

186 It should also be noted that DANI's powers under the Water Order concerning water recreation will be reallocated to the Department of Culture, Arts and Leisure.

187 Section 6(1). The Scottish Environment Protection Agency is placed under similar obligations under sections 32 and 34 of the Environment Act 1995.

188 Section 6(2).

189 The Department's powers to manage the water resource have however been strengthened under the Water Order through the conferral of new powers to control the abstraction of water by means of a licensing system and the imposition of abstraction charges under articles 20 to 22 . 
preservation of amenity and the conservation of flora and fauna. The Department is not required even "to have regard" to the "enhancement" of the natural beauty and amenity of such waters. Nor is the DoE(NI) specifically required to have regard to the conservation of land associated with inland and coastal waters, although it is placed under a duty to have regard to the conservation of geological or physiographical features of special interest and any feature of archaeological, historical, architectural or traditional interest. It is interesting, however, to note that under article 40(1), DANI is required to "have regard to the conservation and enhancement of flora and fauna" in exercising its functions under the Order concerning inland water navigation and water recreation. Furthermore, the Environment Agency's obligation to promote the conservation of the aquatic environment and its flora and fauna is also not placed in direct competition with the needs of other conflicting interests such as industry and agriculture which, under the Water (NI) Order 1999, arguably occupy a higher position in the hierarchy of interests to which the DoE(NI) must have regard. The greater emphasis on nature conservation reflected in the Environment Agency's general duties is further reinforced by section 7 of the Environment Act 1995. Under section 7 the Environment Agency is required to exercise its non-pollution powers (that is, flood defence and fisheries) so as to "further" the conservation and enhancement of natural beauty, flora and fauna, and geological or physiographical features of special interest. When exercising its pollution control functions, the Agency is required to have regard to the "desirability" of conserving and enhancing such features.

During the consultation process surrounding the review of the Water Act (NI) 1972 the Ulster Wildlife Trust ${ }^{190}$ and the Royal Society for the Protection of Birds (NI) ${ }^{191}$ both emphasised the need to strengthen the Department's general commitment to environmental protection and specifically to nature conservation. The UWT pointed out that the list of interests to which the Department was to have regard implied an order of priority, and combined with the term "shall have regard to" placed flora and fauna in a very weak position. Both the UWT and the RSPB recommended that the DoE(NI)'s general nature conservation duties under the proposed Water Order should be at least as strong as those operating in England and Wales. In particular, the RSPB pointed out that the Secretary of State for the Environment, Transport and the Regions, the Secretary of State for Wales, the Director General of Water Services, the Environment Agency and British Waterways all have a duty "to further the conservation and enhancement of natural beauty and the conservation of flora, fauna and geological or physiographical features of interest." The RSPB also pointed out that the need to further nature conservation is underlined by the United Kingdom's biodiversity commitments. The biodiversity process introduces a much more definite role for public bodies in contributing to specific environmental targets, including the enhancement of species and habitats. Hence, the RSPB

190 The UWT made one response during the consultation process on the 24 March 1994 following the publication of the Consultation Paper in December 1993.

191 The RSPB(NI) made two responses during the consultation process. The first was made in response to the publication of the Consultation Paper in December 1993; the second was made in August 1998 in response to the publication of the proposal for a draft Order. 
argued that the requirements of the biodiversity process to meet targets through enhancement work should, therefore, be reflected by legislation where appropriate. Although the RSPB welcomed the wording contained in article 40(1) concerning DANI's general obligations under the Order, they regarded the continued use of the phrase "have regard to" as undesirable in that it suggested that a choice could be made to conserve, enhance or not, which in turn could lead to key opportunities being lost or habitats and wildlife being lost. The RSPB stated that all opportunities for protecting or enhancing nature conservation should be taken if national and local biodiversity targets are to be met; hence they recommended that article 40(1) should be re-worded to reflect this position more clearly. In addition, the RSPB expressed their concern that the $\operatorname{DoE}(\mathrm{NI})$ was not placed under a general duty to secure the proper use of water resources. The Society pointed out that such an overarching duty would require the Department to assess the need for new water resource development and ensure that the most appropriate schemes are licensed, while taking into account the impact on the environment and other users.

The review of the Water Act (NI) 1972 presented the Government with an important opportunity to show the extent of its commitment to embracing the recommendation made by the House of Commons Environment Select Committee that, in the absence of an Environment Agency for Northern Ireland, environmental protection would be given a higher profile in the work of the DoE(NI). ${ }^{192}$ Despite the compelling nature of the arguments raised by the UWF and RSPB and the specific recommendation by the House of Commons Committee that the environment in Northern Ireland be afforded equal legal protection to that in the rest of the United Kingdom, the Government remained unmoved by these recommendations. Although the principal thrust of the Water (NI) Order 1999 is to considerably strengthen the pollution prevention powers available to the $\operatorname{DoE}(\mathrm{NI})$, the general duties imposed on the Department are inconsistent not only with the general duties imposed on the regulator in England and Wales, but also with the largely progressive nature of the Order itself. In addition, the Department's nature conservation duties are inconsistent not only with the United Kingdom's biodiversity commitments, but also with the proposed Biodiversity Strategy published in June 1999 by the Government's advisory group (the Northern Ireland Biodiversity Group) to guide the delivery of the United Kingdom's commitments in this jurisdiction. ${ }^{193}$ While it can certainly be argued that the imposition of strong general obligations is no guarantee that the body will, in practice, show a strong regard for the environment, it is submitted that, in the absence of an independent environmental regulator in Northern Ireland, the nature of the general duties imposed on the DoE are at least of considerable symbolic importance.

192 Environmental Issues in Northern Ireland; HC 39, Session 1990-91, recommendation 25, para 124. In this regard, see also, Milton, Our Countryside Our Concern: The policy and practice of conservation in Northern Ireland, Northern Ireland Environment Link (1990), Chapter 2.

193 Northern Ireland Biodiversity Strategy Proposals, DoE(NI) June 1999. 


\section{(ii) The Obligation to Achieve Water Quality Objectives}

The second significant instance of legislative disparity concerns the Government's failure to place the $\operatorname{DoE}(\mathrm{NI})$ under a statutory duty to exercise its powers under the Water Order so as to achieve statutory water quality objectives at all times in so far as it is practicable to do so. This duty is imposed on the Environment Agency under section 84 of the Water Resources Act 1991 and applies to quality objectives as they are formally established by regulations. While the Agency is not deemed to be in breach of its obligations under section 84 simply by failing to achieve the objectives, it is required to ensure that its powers to grant and review discharge consents and its preventative, remedial and enforcement powers are exercised so as to ensure that the objectives are achieved if practicable. Failure to do so would provide the basis for judicial review proceedings to enforce the Agency's duty in this regard thereby providing third parties an important means of engaging with the enforcement of this vital arm of the regulatory system. ${ }^{194}$ Apart from the issue of disparity with national legislation, the Government's decision to confer the $\operatorname{DoE}(\mathrm{NI})$ with entirely discretionary powers to achieve water quality objectives is even more regrettable in light of the forthcoming enactment of the proposed EU Framework Directive on Water Quality and the highly critical findings of both the Halcrow Report in 1988 and the Comptroller and Auditor General in 1998 concerning the Department's strategy for monitoring water quality in Northern Ireland. The proposed Framework Directive specifically identifies the need for "more intensive monitoring of the extent and nature of pollution and immediate review of all relevant authorisations and discharge permits followed by action based upon the level of risk involved." 195 Although article 6 of the Water Order goes some way towards implementing the requirements of the Directive, the Order does not place the $\operatorname{DoE}(\mathrm{NI})$ under an obligation to conduct any follow-up action in the event of a failure to meet quality objectives by a specified date. ${ }^{196}$ It is anticipated that the Framework Directive will be enacted during the year 2000 .

However, of even greater immediate concern is the DoE(NI)'s failure to conduct an adequate programme of water quality monitoring. In 1988 the Halcrow Report stated that the systems employed by the DoE(NI)'s Water Quality Unit for measuring water quality were "wholly insufficient to measure the performance of the regulatory authority or to give an indication of overall water quality in the Province". ${ }^{197}$ The Halcrow Report stated that

194 Bell, note 136 supra, at, p 466. An additional issue in this regard concerns the Government's failure to impose a timetable for the implementation of water quality objectives - thus far none has been imposed on the Environment Agency. For further discussion of the environmental issues which should be addressed via water quality objectives in Northern Ireland, see the views expressed by the RSPB(NI) during the consultation process, 24 March 1994, para 5.3.

195 Article 13 of the Commission's proposal, COM(1999) 271 final.

196 In this regard, see also the comments submitted to the DoE(NI) by the RSPB(NI) in response to the consultation process, 13 August 1998, para 2.1.

197 Paras. 1.4-1.9. The Halcrow Report was a report commissioned by the DoE(NI) and is therefore an internal document. Although the author requested a copy of the report during the writing of this paper, the Environment and Heritage Service made a decision ( 3 months later) to refuse access on the grounds that it is a 
the length of rivers monitored for water quality was "probably less than adequate to support even the minimal length of rivers classified". ${ }^{198}$ It added, "that if Northern Ireland was to demonstrate a commitment to aquatic environment quality at least comparable to elsewhere in the United Kingdom, a much greater length of rivers should be classified." 199 A decade later the Northern Ireland Auditor General confirmed the findings of the Halcrow Report. The Auditor General pointed out that the DoE(NI) failed to make any response to the Halcrow Report and did not extend the length of rivers monitored to meet the Report's medium and long-term objectives. ${ }^{200}$ Furthermore, the Auditor General reported that the Environment and Heritage Service (EHS) did not collect information with sufficient frequency to properly assess progress against its stated water quality objectives. ${ }^{201}$ The Auditor General also reported that the EHS was still monitoring a substantially lower length of river than comparable regions in the United Kingdom. ${ }^{202}$ However, most damning of all was the Auditor General's decision to record the Department of Agriculture's contention that the monitoring programme was unrepresentative because it did not monitor smaller rural streams in which the water quality was markedly worse than in the major rivers included in the monitoring network. ${ }^{203}$ Although the EHS disputed both DANI's submission and the findings of the Halcrow Report, the Auditor General concluded that because the EHS had not carried out any formal assessment of river monitoring needs to confirm the adequacy of its current monitoring strategy, neither criticism could be dismissed. ${ }^{204}$ Although the EHS has announced its decision to undertake a review of its water quality monitoring strategy which will address the concerns raised by the Halcrow Report, DANI and the Auditor General, given the DoE(NI)'s track record in relation to water quality control and the forthcoming obligations under the Framework Directive, it is regrettable that the Government did not see fit to place the Department (like the Environment Agency) under an obligation to achieve water quality objectives in Northern Ireland in so far as is practicable.

\section{(iii) The Liability of Directors and Senior Company Officers}

A third area of significant disparity between the Water Resources Act 1991 and the Water Order is the lack of provision under the Northern Ireland legislation for the imposition of criminal liability on individual directors, senior company officers and third parties for regulatory offences. Section 217 of the WRA 1991 enables such persons to be held personally liable in criminal law for any offence under the Act that is committed by their company with their consent or connivance, or which can be attributed to

confidential, internal report within the meaning of Regulation 5(2)(c) of the Environmental Information Regulations (NI) 1993. However, reference to Halcrow's core findings can be found in the Report of the Comptroller and Auditor General for Northern Ireland, note 145 supra, at p.39.

198 Report of the Comptroller and Auditor General for Northern Ireland, ibid.

199 Ibid.

200 Ibid, at p 39, para 2.22.

201 Ibid, at p 38, para $2 . .19$

$202 \mathrm{Ibid}$, at p 39, para 2.21.

$203 \mathrm{Ibid}$, at p 40, para 2.24-2.26.

$204 \mathrm{Ibid}$, at p 40, para 2.26 and p 41, para 2.27. 
neglect on their part. Individual liability for corporate offences is one of the most important contemporary strategies employed in the regulation of water pollution in England and Wales and undoubtedly provides a powerful incentive to senior company officers to ensure that their firms operate in compliance with the legislation. ${ }^{205}$ The Standing Committee for Delegated Legislation specifically addressed the matter of criminal liability for directors and company officers during their discussion of the draft Water Order. $\mathrm{Mr}$ John McFall (the Parliamentary Under-Secretary of State for Northern Ireland) provided the Government's rather thin justification for denying the aquatic environment in this jurisdiction this potent form of protection. He explained that because individual liability for corporate offences "has been a thorny [problem] over the years", the Government in Northern Ireland "would prefer to learn from the experience of others on this matter."206

\section{Anticipating the Adoption of the Water Framework Directive}

As already stated, the EC is currently preparing to adopt a new Water Framework Directive. ${ }^{207}$ The purpose of the Directive is to incorporate all requirements for the management of water status into one single document and thus replace the 'first wave' of Directives on water quality adopted during the 1970 s and early 1980s. ${ }^{208}$ Although it has been the subject of considerable controversy, ${ }^{209}$ it is generally accepted that the Framework Directive represents a radical re-thinking of European policy on the aquatic environment. The making of the Water (NI) Order 1999 provided the Government with an ideal opportunity to introduce the statutory basis for implementing the central elements of the Directive; regrettably, this opportunity was missed. Manifestation of this failure has already been discussed above in relation to the obligation to achieve water quality objectives; however, other notable failures to anticipate the requirements of the Directive should also be emphasised. The first striking example occurs in relation to the provision under the Order for making water management programmes. The core mechanism for ensuring the objectives set out in the Directive is the River Basin Management Plan (RBMP), identified by the Commission as the best model for a single system of water management. The Directive will require Governments to integrate a series of specific factors into each management plan; namely, the environmental objectives of the plan, an analysis of the characteristics of the river basin, a review of the environmental impact of human activity, an economic analysis of water use within the river basin, and the results of monitoring programmes carried out. Despite the fact that the Water Framework Directive will require Member

205 For a discussion of the liability of individuals for corporate offences see: Waite, "Criminal liability of Company Directors" (1991) Land Management and Environmental Law Report, 74; and Addison and Mack, "Creating an Environmental Ethic in Corporate America: The Big Stick of Jail Time" (1991) 44 Southwestern Law Journal 1427.

206 Parliamentary Debates, House of Commons: 2 March 1999, p 18.

207 Note 146 supra.

208 Commission Texts, note 146 supra.

209 Howarth, note 160 supra; Staallworthy, 'Water Quality: Proposal for a Draft Water Framework Directive' (1998) 9 Water Law 127; Jordan, "European Community Water Policy Standards; Locked in or Watered Down?", (1999) 37 J Common Mkt Studies 13. 
States to ensure that an integrated RBMP is produced within each river basin, article 57 of the Water (NI) Order 1999 essentially repeats the entirely discretionary powers conferred on the DoE(NI) under the Water Act (NI) 1972 to make water management plans. ${ }^{210}$ It is submitted that in light of the forthcoming adoption of the Framework Directive, the Water Order should have placed the Department under an obligation to make integrated water management plans consistent with the approach adopted by the Directive. A similar approach is taken in relation to the statutory controls imposed on the abstraction and impounding of water. Although the Water Order confers new powers on the DoE(NI) to adopt a system of licensing for the purpose of controlling the abstraction and impounding of water (including the power to establish a system of licence fees), the Department is not placed under an obligation to exercise these powers. The proposed Water Framework Directive will, however, require Member States to introduce controls over the abstraction of fresh surface water and groundwater, including a register of water abstractions and a requirement of prior authorisation for abstraction. ${ }^{211}$ These mandatory controls will also extend to the impounding of water. Not only are the DoE(NI)'s discretionary powers inconsistent with the compulsory nature of the controls required in this context by the Directive, even the introduction of a statutory licensing system will be insufficiently comprehensive as a system of control to satisfy the requirements forthcoming in the Directive. ${ }^{212}$

\section{Ensuring Effective Regulation in Practice}

Throughout the two parts of this article, frequent reference has been made to the highly critical report published in April 1998 by the Comptroller and Auditor General for Northern Ireland concerning the control of river pollution in Northern Ireland. ${ }^{213}$ It is not intended in this section to rehearse all of the specific findings made by the Auditor General. However, given the seminal nature of the report as the first detailed ${ }^{214}$ and publicly available examination of the administration and enforcement of the Water Act (NI) 1972 , it is important to emphasise the overall message conveyed by the Auditor General concerning this function. The central message emerging from the report is that the aquatic environment in this jurisdiction has not been adequately protected in the past. Virtually every aspect of the regulatory practice adopted by the DoE(NI)'s Environment and Heritage Service (EHS) was deemed to be deficient in fundamental respects. The

210 Section 3.

211 Article 13

212 See also the submission made by the RSPB(NI) during the consultation process surrounding the adoption of the Water Order - para 6.1-6.5. The RSPB(NI) also pointed out that the "the absence of comprehensive statutory controls over abstraction will have important implications for the delivery of sustainable water management in Northern Ireland. Even in areas with relatively plentiful water, abstraction control is still essential."

213 Control of River Pollution in Northern Ireland; HC 693, Session 1997-98.

214 Although the legal protection of the aquatic environment was also addressed by the House of Commons Environment Select Committee Report in 1990 (HC 39, Session 1990-91, at paras. 72-80, pp xxiv-xxv) the Auditor General's report is the culmination of a six-year review which provides a much more detailed and specialised examination of this aspect of the EHS regulatory function. 
Auditor General's specific findings concerning the administration and enforcement of the discharge consent system were particularly disquieting given the central role played by this particular mechanism in the regulation of water pollution in Northern Ireland. Four of the shortcomings identified in this regard are sufficiently serious to merit enumeration. First, the report revealed that although the EHS uses the Environment Agency's consent manual as a guide to setting trade consents, it has "no formal documentation of the operation of the consent-setting process in individual cases." 215 This lack of documentation was deemed to "preclude effective management of this function and may expose the EHS to criticism in the event of dispute over individual consent conditions." 216 Secondly, the EHS has only very recently (1997) acquired the technology necessary to measure the overall effectiveness of the consent system. The information produced by the new computerised information system indicated a lower level of compliance than in England and Wales. ${ }^{217}$ Thirdly, the EHS has no formally stated procedures for enforcing discharge consents. ${ }^{218}$ An examination of EHS action against non-compliant dischargers from 1990-95 indicated the its approach to enforcement "did not work in many cases." 219 Not only were dischargers allowed to remain in breach of their consents for "long periods of time before EHS takes any serious enforcement action", 220 even where enforcement action is taken, the EHS approach to enforcement "does not achieve compliance within a reasonable timescale." 221 The EHS typically takes three months to issue warning letters ${ }^{222}$ and even when issued, the Auditor General report described these letters as "surprisingly non-committal, often requiring no action or response from the discharger". ${ }^{223}$ The EHS reported to the Auditor General that the courts in Northern Ireland are "reluctant to convict in cases where an application for consent is outstanding." 224 As a result, where the EHS attempts to prosecute, it has become "normal practice" to apply for a consent as a means of avoiding conviction. ${ }^{225}$ This problem was further compounded by the inordinate delays in issuing consents - instances of two and four-year delays were cited in the report. ${ }^{226}$

The Auditor General's report, which represents the culmination of a six-year examination of the EHS' work, raises very serious questions concerning its capacity to administer and enforce the more sophisticated controls introduced under the Water (NI) Order 1999 in an effective manner. Although it is essential that all of the Auditor General's recommendations are implemented, immediate improvement in certain areas is vital. The EHS must be given the resources necessary to develop an unambiguous and

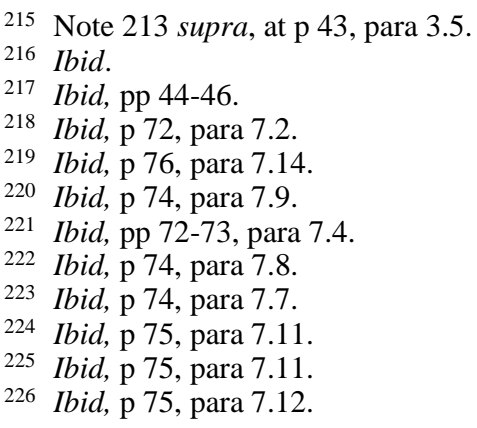


coherent enforcement policy under which all polluters are treated equally. ${ }^{227}$ EHS enforcement policy must also accord with the principles of enforcement established by the Environment Agency: namely, fairness, proportionality, transparency and consistency. ${ }^{228}$ The weaknesses in the monitoring of water quality control, discussed above, must also be addressed as a matter of urgency. Last, but not least, formal targets on compliance with discharge consents must be included as one of the EHS key performance targets with progress published in the EHS Annual Report. If the quality of freshwater in Northern Ireland is to be safeguarded from the potentially destructive effects of the pressure for economic regeneration it is crucial that the discharge consent system - as the central pivot in the regulatory framework - operates effectively.

\section{CONCLUSION}

It is clear from the foregoing analysis of the Water (NI) Order 1999 that its commencement has the potential to mark the beginning of a new era in the regulation of water pollution in Northern Ireland. However, if the promise of increased protection for the aquatic environment represented by the Order is to bear fruit in reality, then further reform is essential. The introduction of more sophisticated legislation on water pollution control is a pointless exercise if the body responsible for delivering pollution control is unable to administer and enforce its provisions in an effective and independent manner. Similarly, modern standards of pollution control cannot be guaranteed if the legal framework within which regulation takes place is weak in a number of fundamental respects in terms of the obligations it imposes on both the regulator and polluter alike. Although the Auditor General for Northern Ireland acknowledged that it was impossible to place a monetary value on improved water quality which could be set against the cost of achieving it, his recent report identified the value of fishing, both commercially and as a tourist amenity, as one possible indication of the importance of clean water for Northern Ireland. ${ }^{229}$ Figures provided by the Department of Agriculture (NI) estimated that commercial fishing on inland waters is worth $£ 4.0$ million to the local economy annually. Angling was considered to be worth $£ 12.0$ million annually and fish farming $£ 3.3$ million. The Auditor General pointed out that, in contrast, angling was worth $£ 70$ million to the Scottish economy annually and $£ 35$ million to the Irish economy. ${ }^{230}$ Although angling in Northern Ireland is currently underdeveloped as a tourist amenity, the Northern Ireland Tourist Board reported that it has "significant growth potential, and even at current levels, it is very significant to local tourist economies." ${ }^{231}$ The protection of the aquatic environment in Northern Ireland is now at a crossroads. If devolution is revived or at the very least, the paramilitary ceasefires hold, the Province is likely to experience a period of sustained and possibly rapid economic development. Northern Ireland's inland waterways - with their traditional image of high environmental quality - are likely to figure prominently as a

\footnotetext{
${ }^{227}$ For a discussion of EHS enforcement policy see, ibid, pp 68-71 and 73-76.

228 Ibid, p 68, para 6.13.

229 Note 213 supra, p 24, para 6.

230 Ibid.

231 Ibid.
} 
natural asset ripe for development as a tourist amenity. In addition, wider economic growth will be attended by greater risks of polluting discharges to water and an increased demand for clean water for both commercial and domestic uses. However, even if political violence does re-emerge, the need for modern standards of pollution control will remain, if for no other reason than because forthcoming EC water Directives will demand the delivery of more effective regulation. In order to safeguard the long-term future of one of Northern Ireland's most valuable economic and cultural assets, the Government must make a commitment to effective and proactive regulation, placing a heavy emphasis on the implementation of the dual principles of polluter pays and pollution prevention - regardless of progress towards wider constitutional settlement. 